Note

Design, Synthesis and Biological Activity of 16,17-Dihydroheronamide C and ent-

\title{
Heronamide C
}

Naoki Kanoh, ${ }^{*[\mathrm{a}, \mathrm{b}]}$ Ryusei Terashima, ${ }^{[\mathrm{cc}]}$ Hiromichi Nishiyama, ${ }^{[\mathrm{c}]}$ Yuta Terajima, ${ }^{[\mathrm{c}]}$ Shota Nagasawa, ${ }^{[\mathrm{c}]}$

Yusuke Sasano, ${ }^{[\mathrm{c}]}$ Yoshiharu Iwabuchi, ${ }^{[\mathrm{cc}]}$ Hiroaki Saito, ${ }^{[\mathrm{d}]}$ Syusuke Egoshi, ${ }^{\left[{ }^{[\mathrm{e}]}\right.}$ Kosuke Dodo, ${ }^{[\mathrm{e}]}$ Mikiko

Sodeoka, ${ }^{[\mathrm{e}]}$ Chengqian Pan, ${ }^{[\mathrm{ff}]}$ Yoshinobu Ikeuchi, ${ }^{[\mathrm{f}]}$ Shinichi Nishimura,${ }^{[\mathrm{g}]}$ and Hideaki Kakeya ${ }^{[\mathrm{f}]}$

[a] School of Pharmacy and Pharmaceutical Sciences, Hoshi University, 2-4-41 Ebara, Shinagawa-ku,

Tokyo 142-8501, JAPAN. E-mail: n-kanoh@hoshi.ac.jp

[b] Institute of Medicinal Chemistry, Hoshi University, 2-4-41 Ebara, Shinagawa-ku, Tokyo 142-8501,

JAPAN

[c] Graduate School of Pharmaceutical Sciences, Tohoku University, 6-3 Aza-aoba, Aramaki, Aoba-

ku, Sendai 980-8578, JAPAN

[d] Faculty of Pharmaceutical Sciences, Hokuriku University, 3 Kanagawamachi, Kanazawa, Ishikawa,

920-1181, JAPAN

[e] Synthetic Organic Chemistry Laboratory, RIKEN Cluster for Pioneering Research, 2-1 Hirosawa,

Wako, Saitama 351-0198, JAPAN 
[f] Graduate School of Pharmaceutical Sciences, Kyoto University, 46-29 Shimo-Adachi-cho, Yoshida, Sakyo-ku, Kyoto 606-8501, JAPAN

[g] Department of Biotechnology, Collaborative Research Institute for Innovative Microbiology, The University of Tokyo, Tokyo 113-8657, JAPAN

\begin{abstract}
16,17-Dihydroheronamide C (8) and ent-heronamide C (ent-1) were designed as probes for the mode-of-action analysis of heronamide C (1). These molecules were synthesized by utilizing a highly modular strategy developed in the preceding paper. Evaluation of the antifungal activity of these compounds revealed the exceptional importance of the $\mathrm{C} 16-\mathrm{C} 17$ double bond for the biological activity of heronamide $\mathrm{C}$, and the existence of chiral recognition between heronamide $\mathrm{C}(\mathbf{1})$ and cell membrane components.
\end{abstract}

\title{
Introduction
}

In the preceding paper, ${ }^{1}$ we developed a highly modular strategy for the synthesis of heronamide C-type polyene macrolactams ${ }^{2-4}$ featuring modular Suzuki coupling utilizing MIDA boronate ester and borylcupration/protonation of internal alkynes. By utilizing the developed strategy, 8-deoxyheronamide C (2) and four heronamide C-like molecules named heronamidoids $\alpha-\delta$ were successfully synthesized. Synthesis of heronamidoids enabled the conformational and reactivity 
analysis of the 20-membered polyene macrolactams. As an application of the modular synthetic strategy, as well as a part of our program directed toward the mode-of-action study of heronamides, we herein report the design, synthesis, and biological activity of 16,17-dihydroheronamide $\mathrm{C}(\mathbf{8})$ and ent-heronamide C (ent-1) (Figure 1).

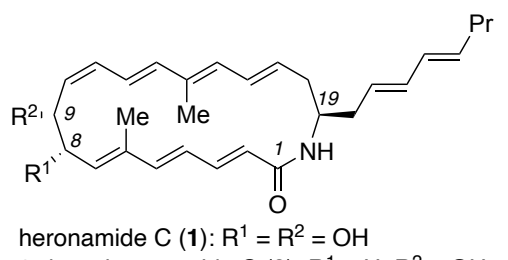

8-deoxyheronamide $\mathrm{C}(2): \mathrm{R}^{1}=\mathrm{H}, \mathrm{R}^{2}=\mathrm{OH}$ heroemide $C$ diacetate $(\mathbf{3}): R^{1}=R^{2}=O A c$
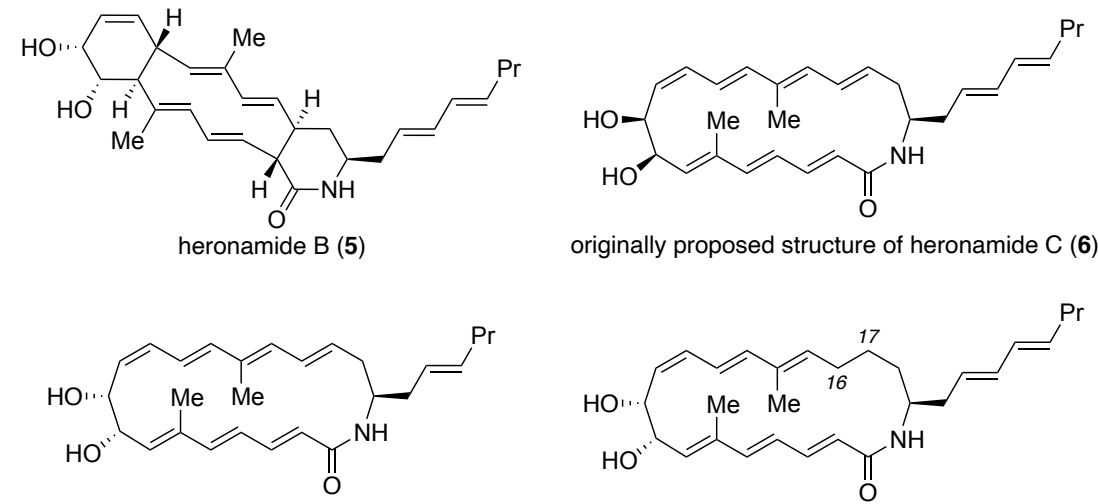

BE-14106 (GT-32A) (7)

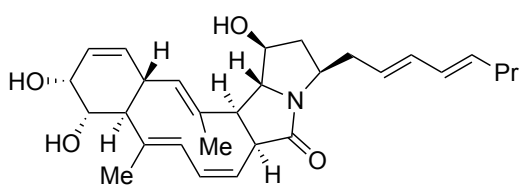

heronamide $\mathrm{A}(4)$

originally proposed structure of heronamide C $(6)$

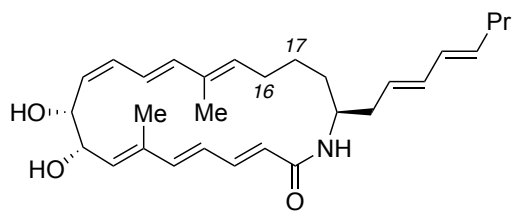

16,17-dihydroheronamide C (8)

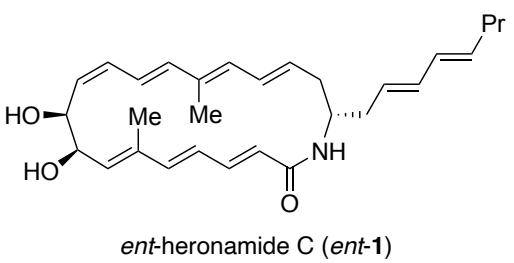

Figure 1. Structures of heronamides (selected) and their synthetic analogues

\section{Results and Discussion}

Design of molecular probes for the mode-of-action studies of heronamide $\mathrm{C}$ 
Having established a unified strategy, ${ }^{1}$ we decided to design and synthesize molecular probes for the mode-of-action studies of heronamide C (1). Previously, we showed that heronamide C (1) and 8-deoxyheronamide C (2) bind to liposomes consisting of lipids having saturated hydrocarbon chains in an irreversible manner. ${ }^{5}$ In addition, structure-activity relationship studies revealed that, among the congeners 1-5 (Figure 1), only 20-membered macrolactams $\mathbf{1}$ and $\mathbf{2}$ having hydroxyl group(s) possess not only growth inhibition activity against fission yeast cells, ${ }^{5,6}$ but also the ability to induce abnormal cell morphology of the yeast cells. ${ }^{5}$ The reversal morphological effect of 1 on mammalian cells was also reported by Capon's group. ${ }^{7}$ Importantly, heronamides A (4) and B (5), compounds derived from heronamide C (1) under aerobic/thermal and photochemical conditions, ${ }^{5-7}$ respectively (Figure 2), lost all of these activities. Moreover, between the compounds $\mathbf{1}$ and $\mathbf{2}$, compound $\mathbf{2}$ was shown to have a prominent selectivity profile against fission yeast cells: it inhibited the growth of wild-type fission yeast cells (MIC $5.9 \mu \mathrm{M}$ ) while mutant yeast cells lacking the ergosterol biosynthetic gene (erg2, erg31 and erg32, sts1/erg4, or erg5) were tolerant to 2 up to a concentration of $46 \mu \mathrm{M} .{ }^{5}$ It was later shown that both the originally proposed structure of heronamide C (6) and BE-14106 (a.k.a. GT-32A) (7), an analogue having a truncated side chain, have reduced antifungal activity when compared with $\mathbf{1} .^{6,8}$

These results suggested that heronamide C-type molecules interact with cell membrane lipids having saturated hydrocarbon chains and perturb the structure of the membrane in cells. Indeed, 
molecular dynamic simulation of heronamides in a bilayer of 1,2-dimyristoyl-sn-glycero-3phosphorylcholine (DMPC) suggested that heronamide C (1) and 8-deoxyheronamide C (2) resided in the bilayer to form head-to-tail contacts with DMPC, as cholesterol does (Supporting Figure 1).

However, the actual localization and fates of these reactive heronamide C-type macrolactams in lipid bilayers and living cells have not been studied experimentally.

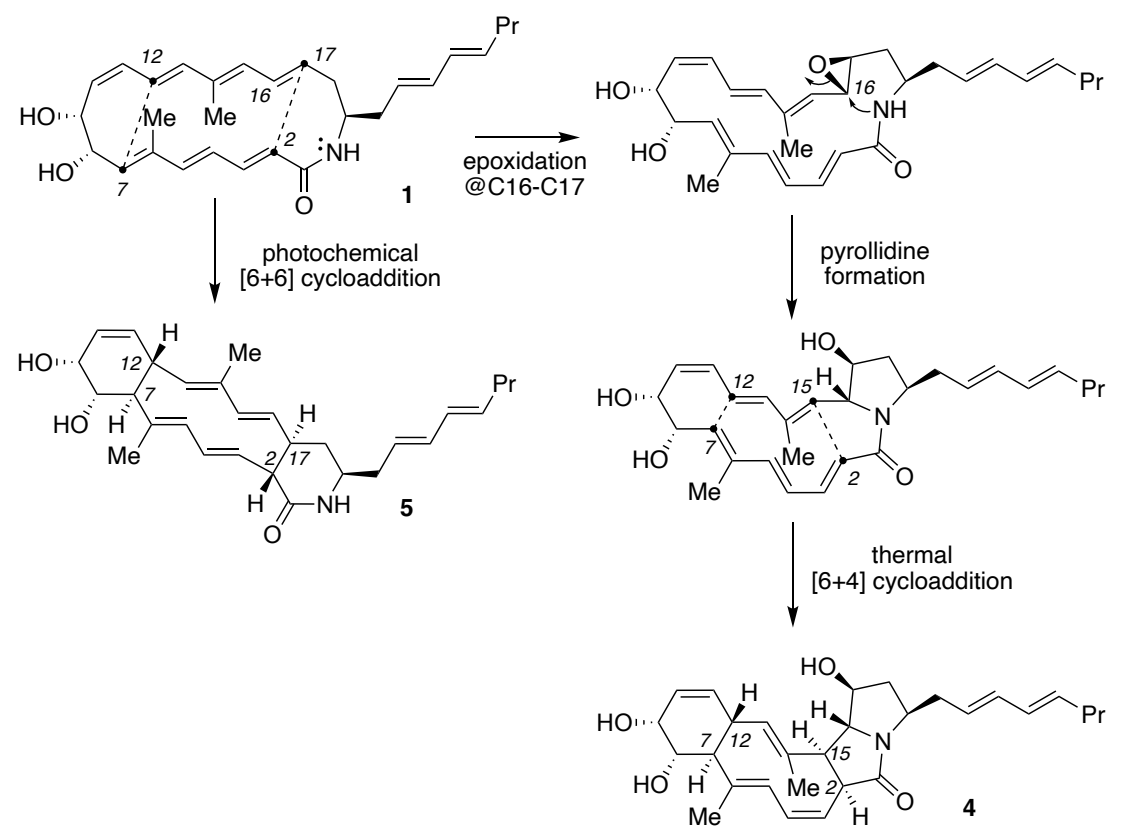

Figure 2. Biogenetic transformation of heronamide C (1) to heronamides A (4) and B (5).

To understand the localization and fates of $\mathbf{1}$ in living cells, we planned live cell time-course experiments of 1 by using a Raman imaging technique. ${ }^{9}$ Usually, alkyne tags are used for visualization of small molecules in live cell Raman imaging, ${ }^{10}$ but a recent study showed that polyenes could be 
observed in cells. ${ }^{11}$ Indeed, a strong Raman signal at $\sim 1600 \mathrm{~cm}^{-1}$ was observed when heronamide $\mathrm{C}$ (1) on a quartz substrate was scanned by using a Raman microscope with $532 \mathrm{~nm}$ excitation (Supporting Figure 2). However, the signal intensity diminished as the measurement was repeated, suggesting laser-induced degradation and/or a photochemical reaction, possibly including $[6 \pi+6 \pi]$ cycloaddition (Figure 2). We therefore decided to design a stabilized heronamide $\mathrm{C}$ analog that behaves similarly to heronamide C (1) in the lipid membrane but does not degrade/react like heronamide $\mathrm{C}(\mathbf{1})$.

Based on the molecular mechanics (MM) calculation, we herein designed 16,17dihydroheronamide $\mathrm{C}$ (8) (Figure 1). The designed compound 8 lacks a C16-C17 olefin that is needed not only for the $[6 \pi+6 \pi]$ cycloaddition leading to heronamide B (5), but also for C16-C17 epoxidation, the first step of the reaction sequence leading to heronamide A (4) (Figure 2). Importantly, the calculated macrocycle conformation of the 16,17-dihydro analogue was found to be very similar to that of heronamide C (1) (Figure 3). MD simulation also showed that 16,17-dihydroheronamide C (8) in a DMPC lipid bilayer behaved in the same manner as heronamide $\mathrm{C}(\mathbf{1})$ and 8-deoxyheronamide $\mathrm{C}$ (2) (Supporting Figure 1-3).

In addition to 16,17-dihydroheronamide $\mathrm{C}(\mathbf{8})$, we also designed ent-heronamide $\mathrm{C}$ (ent-1) as an enantiomeric probe of heronamide $\mathrm{C}(\mathbf{1})$. We have shown that diastereomeric analogue $\mathbf{6}$ (Figure 1) having $\mathrm{C} 8, \mathrm{C} 9$-diol functionalities possesses 80 -fold less-potent antifungal activity than that of 
heronamide $\mathrm{C}(\mathbf{1}){ }^{6}{ }^{6}$ We also showed in the preceding paper $^{1}$ that truncated compounds named heronamidoids $\gamma$ and $\delta$, which have the same relative stereochemistries as $\mathbf{1}$ and $\mathbf{6}$, respectively, differ in their stable confirmation indicating that the stable conformation of compounds $\mathbf{1}$ and $\mathbf{6}$ also differ significantly. Thus, we are interested in whether ent-1 possesses antifungal activity. If there is a difference in the antifungal activity between heronamide C (1) and ent-1, chiral interaction of $\mathbf{1}$ with cell membrane component(s) would be strongly suggested.
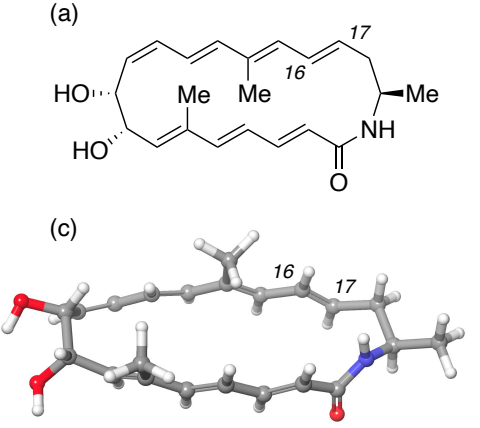

(b)

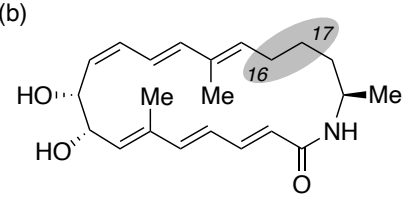

(d)

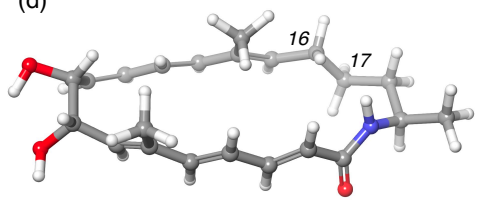

Figure 3. Most stable conformers of macrocycles of heronamide $C$ and its 16,17-dihydro analogue.

Chemical structures ( $a$ and $b$ ) and their calculated most stable conformers ( $c$ and d) of the macrocycle moiety of heronamide $\mathrm{C}$ ( $\mathrm{a}$ and $\mathrm{c}$ ) and its 6,17-dihydro analogue (b and d).

Conformational search (OPLS2015, no solvent) and energy minimization was performed on

Macromodel ver.11.0.

To synthesize probe 8, C14-C27 fragment $\mathbf{1 0}$ was needed along with $\mathrm{C} 1-\mathrm{C} 13$ fragment $\mathbf{9}$, 
which could be synthesized from L-ribose (Scheme 1a). ${ }^{1}$ Fragment $\mathbf{1 0}$ would be synthesized from chiral enyneamine $\mathbf{1 1}$ by the established protocol including a highly regioselective borylcupuration/protonation sequence. ${ }^{1}$ ent-Heronamide C (ent-1) would be synthesized from ent-9 ${ }^{1}$ and C14-C27 fragment 12, whose enantiomer was synthesized in the preceding $\operatorname{paper}^{1}$ (Scheme 1b).

(a)<smiles>C=CC=CC=CC(=O)NC(CC=CC=CCC)CCCC=CC1=CC(O)C(O)C=CC=C1</smiles>

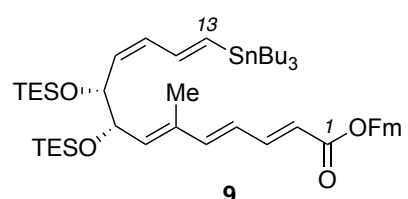

Me

8
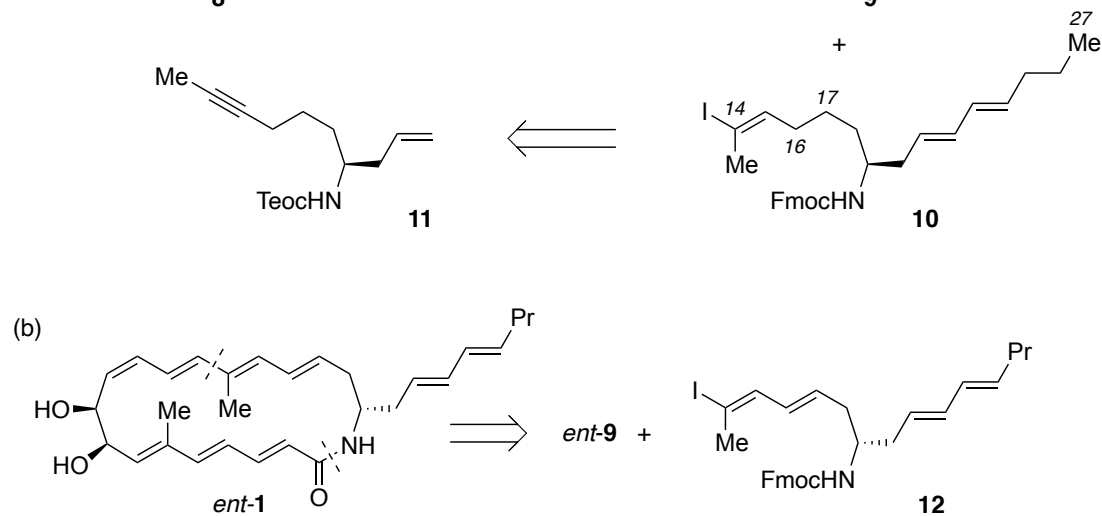

Scheme 1. Synthetic plan of 16,17-dihydroheronamide C (8) and ent-heronamide C (ent-1)

\section{Synthesis of 16,17-dihydroheronamide C and ent-heronamide C}

Synthesis of 16,17-dihydroheronamide C (8) is shown in Scheme 2. 5-Heptynal (13), which could be easily synthesized from 2-methyl-1,3-cyclohexanedione, ${ }^{12,13}$ was treated under Kobayashi transfer aminoallylation reaction conditions ${ }^{14}$ using (1S)-camphorquinone derivative $\mathbf{1 4}$ to afford homoallylamine 15 in $66 \%$ yield and 95\% ee. Teoc protection of the resulting amine by using Ghosh's 
procedure ${ }^{15}$ with carbonate 16 afforded Teoc-protected enyneamine 17 in $81 \%$ yield. Dihydroxylation of the monosubstituted olefin of $\mathbf{1 7}$ followed by cleavage of the resulting diol provided aldehyde $\mathbf{1 8}$, which was subjected to the Takai-Utimoto olefination conditions using dichloromethylboronic acid pinacol ester $19^{16}$ to afford (E)-vinylboronic acid pinacol ester $\mathbf{2 1}$ in $78 \%$ yield in a highly stereoselective manner $(E: Z=>95: 5)$. Direct introduction of the $(E)$-vinylboronic acid ester unit on $\mathbf{1 7}$ using vinylboronic acid MIDA ester $\mathbf{2 0}$ under olefin metathesis conditions did not work, possibly due to the intramolecular enyne metathesis of $\mathbf{1 7}$. 


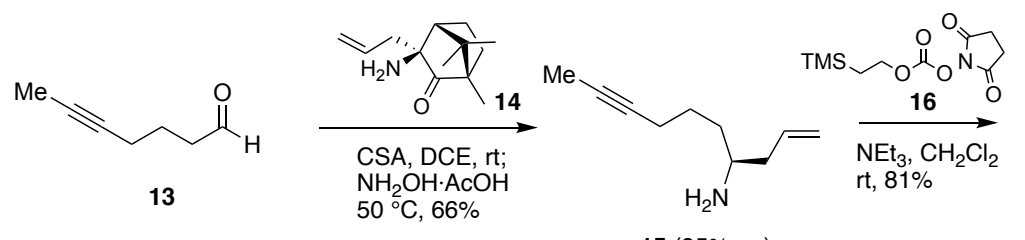

15 (95\% ee)
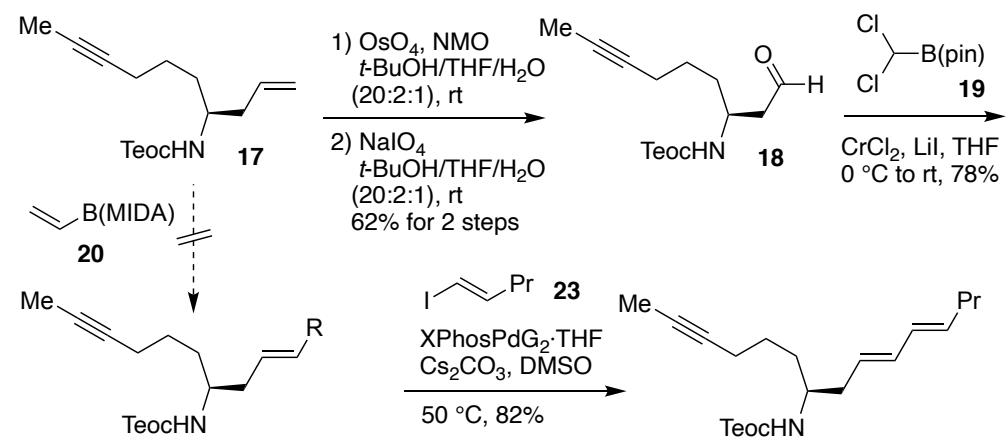

21: $\mathrm{R}=\mathrm{B}($ pin $)(E: Z=>95: 5)$

22: $R=B($ MIDA) (not obtained)

24
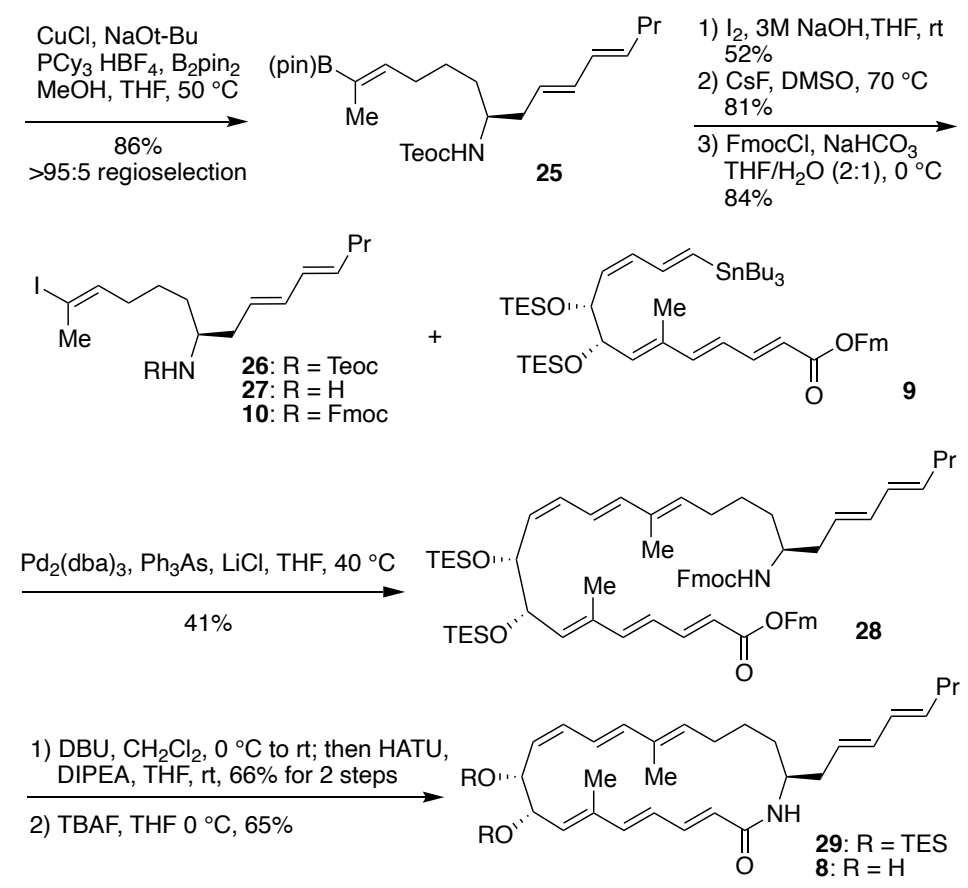

Scheme 2. Synthesis of 16,17-dihydroheronamide C (8)

Fragment assembly and macrolactam formation were performed as follows. Suzuki coupling

of pinacol ester $\mathbf{2 1}$ and vinyl iodide $\mathbf{2 3}$ afforded dieneyne $\mathbf{2 4}$ in $82 \%$ yield. Borylcupration/protonation 
of dienyne $\mathbf{2 4}$ worked well to produce triene $\mathbf{2 5}$ in $86 \%$ yield. It should be noted that the reaction proceeded in a highly regio- and chemoselective manner in the presence of the conjugated diene moiety. Iodination of $\mathbf{2 5}$ followed by Teoc deprotection and Fmoc protection gave C14-C27 unit $\mathbf{1 0}$ in $35 \%$ for three steps. Stille coupling of $\mathbf{1 0}$ with $\mathrm{C} 1-\mathrm{C} 13$ fragment $\mathbf{9}$ followed by the simultaneous deprotection of Fm and Fmoc groups, macrolactamization, and TES deprotection provided 16,17dihydroheronamide C (8) in 18\% yield for 4 steps.

Synthesis of ent-heronamide C (ent-1) is summarized in Scheme 3. C1-C13 Fragment ent-9 and C14-C27 fragment 12 were prepared from D-ribose and homoallylamine $\mathbf{3 0}$ (95\% ee), respectively. ${ }^{1}$ These fragments were coupled under Stille conditions to give coupling product $\mathbf{3 1}$ in $40 \%$ yield, which was then treated with DBU followed by HATU to generate TES-protected entheronamide C (32) in 53\% yield over 2 steps. Finally, by deprotection of TES groups in $\mathbf{3 2}$ using TBAF, ent-heronamide C (ent-1) was obtained in 90\% yield. 


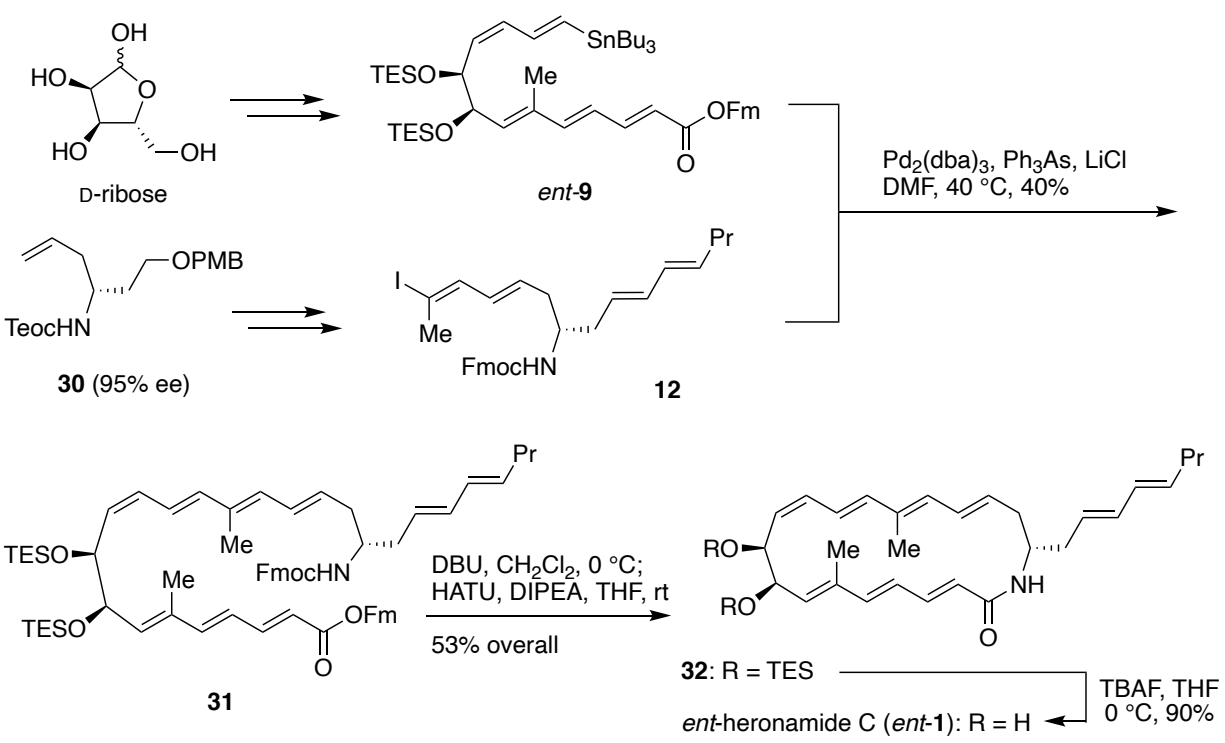

Scheme 3. Synthesis of ent-heronamide C (ent-1).

The CD spectra of these synthetic compounds 8 and ent-1, as well as 8-deoxyheronamide C (2), were measured in DMSO. ${ }^{5}$ 16,17-Dihydroheronamide C (8) showed a positive Cotton effect, as 8deoxyheronamide C (2) did, suggesting that they have similar conformations in solution (Supporting Figure 3). Understandably, ent-heronamide C (ent-1) displayed a negative Cotton effect nearly symmetrical to that of 8-deoxyheronamide C. ${ }^{5}$ In addition, 16,17-dihydroheronamide C (8) showed a characteristic Raman signal at $\sim 1600 \mathrm{~cm}^{-1}$, indicating the possibility of its use in the Raman imaging experiment (Supporting Figure 4).

\section{Biological activity of 16,17-dihydroheronamide $C$ and ent-heronamide $C$}

The growth inhibition activities of 16,17-dihydroheronamide C (8) and ent-heronamide C (ent-1) 
against fission yeast cells were examined ${ }^{17}$ using 8-deoxyheronamide $\mathrm{C}(2)$ as a positive control (Figure 4). Under the experimental conditions used here, the $\mathrm{IC}_{50}$ values of ent-heronamide $\mathrm{C}$ (ent-1) against the wild-type strain, $\operatorname{erg} 2 \Delta$ mutant, ${ }^{18}$ and $\operatorname{erg} 31 \Delta \operatorname{erg} 32 \Delta$ double mutant ${ }^{18}$ were $0.26,0.44$, and $0.38 \mu \mathrm{M}$, respectively. Compared with 8-deoxyheronamide C (2), ent-heronamide C (ent-1) showed 2-fold more potent activity against the wild type cells. Since 8-deoxyheronamide C (2) shows 20-fold less potent activity against the wild-type cells, ${ }^{5}$ ent-1 turned out to be 10 -fold less potent than heronamide C (1). ${ }^{5}$ This result indicated the existence of chiral recognition between heronamide C (1) and cell membrane component(s).

Ent-heronamide C (ent-1) was found to be slightly active against wild type yeast cells. This sensitivity profile and cellular phenotype (data not shown) of ent-1 against wild type yeast and mutants had close similarity with those of $\mathbf{1},{ }^{5,6}$ suggesting that the mode-of-action of ent-1 would be same as those of $\mathbf{1}$ and $\mathbf{2}$. These results also indicated that the relative stereochemistries at the $\mathrm{C} 8, \mathrm{C} 9$, and $\mathrm{C} 19$ stereocenters were important not only for the activity strength but also for the selectivity profile. 

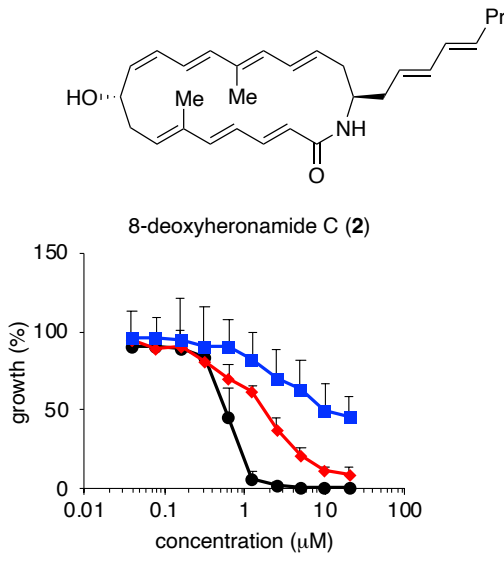

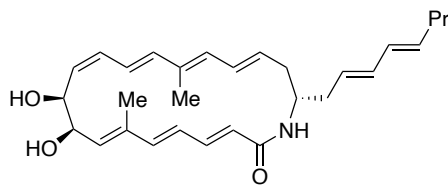

ent-heronamide $\mathrm{C}$ (ent-1)

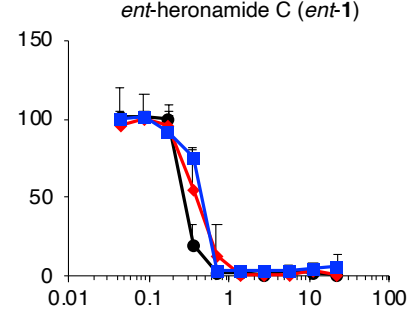

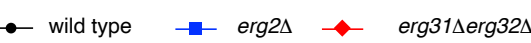

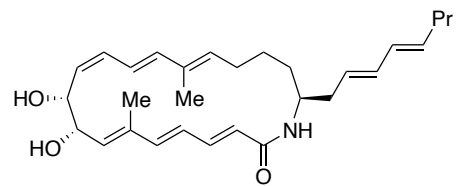

16,17-dihydroheronamide C (8)

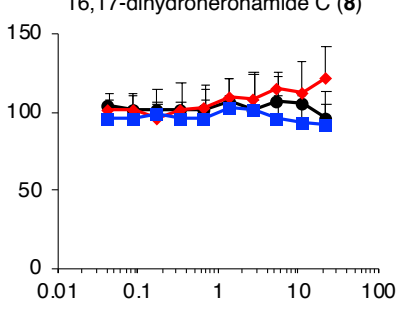

Figure 4. Growth inhibition activity of heronamides toward fission yeast cells

To our surprise, 16,17-dihydroheronamide C (8) did not show any growth inhibition up to a concentration of $50 \mu \mathrm{M}$. This result indicated that the $\mathrm{C} 16-\mathrm{C} 17$ double bond is crucial for the antifungal activity of $\mathbf{1}$. Possible explanations for this result would be as follows: (1) recognition of heronamide C (1) by the cell membrane component(s) is quite susceptible to the conformation of 1 and/or the environment around the $\mathrm{C} 16-\mathrm{C} 17$ double bond, ${ }^{19}$ or (2) the susceptibilities of heronamide C toward the thermal/aerobic and photochemical reactions and/or the reaction products (or intermediates) are essential for the biological activity. Although we can not conclude which explanation is correct at this stage, ent-heronamide C (ent-1) and 16,17-dihydroheronamide C (8) would be useful probes in a future study to understand the cellular activity of heronamide C-type natural products. 


\section{Summary}

In this study, we designed and synthesized 16,17-dihydroheronamide C (8) and ent-heronamide C (ent-

1) as probes for the mode-of-action studies of heronamides. A highly modular strategy developed in

the preceding paper $^{1}$ was successfully applied for the synthesis of these probes. Examination of the antifungal activity of ent-heronamide $\mathrm{C}$ (ent-1) and 16,17-dihydroheronamide $\mathrm{C}(\mathbf{8})$ revealed (1) the presence of chiral recognition between heronamide C (1) and cellular components, which increases the potency of the biological activity but is not essential for that, and (2) an unexpected significance of the C16-C17 double bond for the biological activity of heronamide C (1). Detailed analyses of mode-of-action studies using ent-heronamide C (ent-1) and 16,17-dihydroheronamide C (8) as positive and negative probes, respectively, including live-cell Raman imaging studies, are now in progress and will be reported in due course. 


\section{Experimental Section}

\section{General Remarks}

All reactions were carried out under an argon atmosphere with dehydrated solvents under anhydrous conditions, unless otherwise noted. Dehydrated THF and $\mathrm{CH}_{2} \mathrm{Cl}_{2}$ were purchased from Kanto Chemical Co., Inc. Other solvents were dehydrated and distilled according to standard protocols. Reagents were obtained from commercial suppliers and used without further purification, unless otherwise noted. Reactions were monitored by thin-layer chromatography (TLC) carried out on silica gel plates (Merck Kieselgel 60 F254). Column chromatography was performed on Silica gel 60N (Kanto Chemical Co., Inc.; spherical, neutral, 63-210 $\mu \mathrm{m}$ ), and flash column chromatography was performed on Silica gel 60N (Kanto Chemical Co., Inc.; spherical, neutral, 40-50 $\mu \mathrm{m}$ ). Optical rotations were measured on a JASCO P-2200 Digital Polarimeter at rt, using the sodium D line. CD spectra were measured on a JASCO J-720 spectropolarimeter. IR spectra were recorded on a JASCO FT/IR-410 Fourier Transform Infrared Spectrophotometer or Travel-IR ${ }^{\text {TM }} .{ }^{1} \mathrm{H}-\mathrm{NMR}$ (400 and 600 $\mathrm{MHz}$ ) and ${ }^{13} \mathrm{C}-\mathrm{NMR}$ spectra (100 and $150 \mathrm{MHz}$ ) were recorded on a JEOL JNM-AL-400, and JEOL JNM-ECA-600 or JEOL ECZ600 spectrometers, respectively. For ${ }^{1} \mathrm{H}-\mathrm{NMR}$ spectra, chemical shifts ( $\delta)$ are given from TMS $(0.00 \mathrm{ppm})$ in $\mathrm{CDCl}_{3}$ or a $\mathrm{C} 2$ proton $(8.71 \mathrm{ppm})$ of deuteriopyridine in pyridine- $d_{5}$ as internal standards. For ${ }^{13} \mathrm{C}-\mathrm{NMR}$ spectra, chemical shifts $(\delta)$ are given from $\mathrm{CDCl}_{3}$ (77.0 ppm) or a $\mathrm{C} 2$ carbon of pyridine- $d_{5}(149.2 \mathrm{ppm})$ as internal standards. The following 
abbreviations were used to explain the multiplicities: $\mathrm{s}=$ singlet, $\mathrm{d}=$ doublet, $\mathrm{t}=$ triplet, $\mathrm{q}=$ quartet, sext $=$ sextet, sept $=$ septet, $\mathrm{m}=$ multiplet, $\mathrm{br}=$ broad. Mass spectra were recorded on JEOL JMSDX303, JEOL JNM-AL500, JEOL JMS-700, and Thermo Scientific Exactive mass spectrometers.

\section{Amine 15}

To a solution of ketoamine $\mathbf{1 4}^{14}(2.01 \mathrm{~g}, 8.69 \mathrm{mmol})$ and aldehyde $\mathbf{1 3}^{20}(1.05 \mathrm{~g}, 9.54 \mathrm{mmol})$ in $1,2-$ dichloroethane $(20 \mathrm{~mL})$ was added CSA $(22.2 \mathrm{mg}, 0.95 \mathrm{mmol})$ at $0{ }^{\circ} \mathrm{C}$. The mixture was allowed to warm to room temperature and stirred for $23.5 \mathrm{~h}$. Then, a solution of $\mathrm{HONH}_{2} \cdot \mathrm{AcOH}(0.5 \mathrm{M}$ in methanol, $40 \mathrm{~mL}$ ) was added to the reaction mixture. After being stirred at $50{ }^{\circ} \mathrm{C}$ for $3 \mathrm{~h}$, the mixture was allowed to cool to room temperature. The mixture was acidified with $6 N$ aq. $\mathrm{HCl}$ to $\mathrm{pH} \sim 1$ and washed with $\mathrm{CH}_{2} \mathrm{Cl}_{2}(30 \mathrm{~mL})$. The resulting aqueous layer was basified to $\mathrm{pH} \sim 10$ with $6 \mathrm{~N}$ aq. $\mathrm{NaOH}$ and extracted with $\mathrm{CH}_{2} \mathrm{Cl}_{2}(50 \mathrm{~mL} \times 5)$. The combined organic layers were dried over $\mathrm{Na}_{2} \mathrm{SO}_{4}$, filtered, and concentrated in vacuo. The residue was purified by silica gel column chromatography $\left(\mathrm{MeOH} / \mathrm{CHCl}_{3}=1 / 10\right)$ to give amine $15(950 \mathrm{mg}, 6.28 \mathrm{mmol}, 66 \%)$ as a colorless oil. 15: $[\alpha]_{\mathrm{D}}{ }^{29}-4.4\left(c 0.224, \mathrm{CHCl}_{3}\right)$; IR (neat): 3075, 2920, 2859, 1639, 1575, 1438, 996, $915 \mathrm{~cm}^{-1} ;{ }^{1} \mathrm{H}-$ NMR (400 MHz, $\left.\mathrm{CDCl}_{3}\right): \delta 5.86-5.73(\mathrm{~m}, 1 \mathrm{H}), 5.11(\mathrm{~d}, J=5.8 \mathrm{~Hz}, 1 \mathrm{H}), 5.08(\mathrm{~s}, 1 \mathrm{H}), 2.85-2.74(\mathrm{~m}$, $1 \mathrm{H}), 2.30-2.19(\mathrm{~m}, 1 \mathrm{H}), 2.19-2.10(\mathrm{~m}, 1 \mathrm{H}), 2.06-1.92(\mathrm{~m}, 1 \mathrm{H}), 1.78(\mathrm{t}, J=2.4 \mathrm{~Hz}, 3 \mathrm{H}), 1.66-1.42(\mathrm{~m}$, $3 \mathrm{H}), 1.43-1.33(\mathrm{~m}, 1 \mathrm{H}), 1.25$ (brs, $1 \mathrm{H}) ;{ }^{13} \mathrm{C}-\mathrm{NMR}\left(100 \mathrm{MHz}, \mathrm{CDCl}_{3}\right): \delta 135.8,117.3,79.0,75.7,50.2$, 
42.6, 36.9, 25.8, 18.8, 3.4; HRMS (FAB): calcd for $\mathrm{C}_{10} \mathrm{H} 1_{18} \mathrm{~N}\left([\mathrm{M}+\mathrm{H}]^{+}\right)$152.1439, found 152.1407.

\section{Teoc-protected amine 17}

To a solution of amine $\mathbf{1 5}(30 \mathrm{mg}, 0.20 \mathrm{mmol})$ and carbonate $16^{21}(67 \mathrm{mg}, 0.26 \mathrm{mmol})$ in $\mathrm{CH}_{2} \mathrm{Cl}_{2}(1.3$ $\mathrm{mL})$ was added $\mathrm{NEt}_{3}(0.030 \mathrm{~mL}, 0.30 \mathrm{mmol})$ at room temperature. After being stirred for $45 \mathrm{~min}$, the mixture was concentrated in vacuo. The residue was diluted with sat. aq. $\mathrm{NaHCO}_{3}(2 \mathrm{~mL})$ and extracted with EtOAc (5 mL x 3). The combined layers were washed with brine $(2 \mathrm{~mL})$, dried over $\mathrm{Na}_{2} \mathrm{SO}_{4}$, filtered, and concentrated in vacuo. The residue was purified by silica gel column chromatography $(\mathrm{EtOAc} /$ hexane $=1 / 15)$ to give Teoc-protected amine $17(51 \mathrm{mg}, 0.17 \mathrm{mmol}, 86 \%)$ as a colorless oil.

17: $[\alpha]_{\mathrm{D}}^{25}-10.7\left(c 0.214, \mathrm{CHCl}_{3}\right)$; IR (neat): 2952, 1691, 1534, 1251, 1063, $837 \mathrm{~cm}^{-1} ;{ }^{1} \mathrm{H}-\mathrm{NMR}(400$ $\left.\mathrm{MHz}, \mathrm{CDCl}_{3}\right): \delta 5.81-5.74(\mathrm{~m}, 1 \mathrm{H}), 5.10(\mathrm{~s}, 1 \mathrm{H}), 5.07(\mathrm{~s}, 1 \mathrm{H}), 4.39(\mathrm{brs}, 1 \mathrm{H}), 4.14(\mathrm{t}, J=8.2 \mathrm{~Hz}, 2 \mathrm{H})$ 3.70 (brs, $1 \mathrm{H}), 2.29-2.15(\mathrm{~m}, 1 \mathrm{H}), 2.15-2.04(\mathrm{~m}, 2 \mathrm{H}), 1.77(\mathrm{t}, J=2.4 \mathrm{~Hz}, 3 \mathrm{H}), 1.68-1.37(\mathrm{~m}, 4 \mathrm{H}), 0.97$ (t, $J=8.2 \mathrm{~Hz}, 2 \mathrm{H}), 0.04(\mathrm{~s}, 9 \mathrm{H}) ;{ }^{13} \mathrm{C}-\mathrm{NMR}\left(100 \mathrm{MHz}, \mathrm{CDCl}_{3}\right): \delta 156.3,134.2,117.8,78.7,75.9,62.8$, 50.1, 39.6, 33.9, 25.4, 18.6, 17.7, 3.4, -1.5; HRMS (FAB): calcd for $\mathrm{C}_{16} \mathrm{H}_{30} \mathrm{NO}_{2} \mathrm{Si}\left([\mathrm{M}+\mathrm{H}]^{+}\right)$296.2046, found 296.2041 .

\section{Aldehyde 18}


Teoc-protected amine $17(100 \mathrm{mg}, 0.338 \mathrm{mmol})$ was dissolved in a mixture of $t$ - $\mathrm{BuOH} / \mathrm{THF} / \mathrm{H}_{2} \mathrm{O}$ (10:2:1, $4 \mathrm{~mL})$. To the solution was added 4-methylmorpholine $N$-oxide $(158 \mathrm{mg}, 1.35 \mathrm{mmol})$ and $\mathrm{OsO}_{4}\left(0.10 \mathrm{M}\right.$ in $\left.\mathrm{H}_{2} \mathrm{O}, 16.9 \mu \mathrm{mol}\right)$ at room temperature. The reaction mixture was stirred at the same temperature for $4 \mathrm{~h}$ and then quenched with sat. aq. $\mathrm{Na}_{2} \mathrm{~S}_{2} \mathrm{O}_{3}(5 \mathrm{~mL})$. The separated aqueous layer was extracted with EtOAc $(5 \mathrm{~mL} \times 3)$. The combined organic layers were washed with brine $(5 \mathrm{~mL})$, dried over $\mathrm{Na}_{2} \mathrm{SO}_{4}$, filtered, and concentrated in vacuo. The crude product was dissolved in a mixture of $t$ $\mathrm{BuOH} / \mathrm{THF} / \mathrm{H}_{2} \mathrm{O}(20: 2: 1,1 \mathrm{~mL})$ and $\mathrm{NaIO}_{4}(218 \mathrm{mg}, 1.01 \mathrm{mmol})$ was added at room temperature. After stirring for $9.5 \mathrm{~h}$, sat. aq. $\mathrm{Na}_{2} \mathrm{~S}_{2} \mathrm{O}_{3}(5 \mathrm{~mL})$ was added. The separated aqueous layer was extracted with EtOAc $(5 \mathrm{~mL} \times 3)$. The combined organic layers were washed with brine $(5 \mathrm{~mL})$, dried over $\mathrm{Na}_{2} \mathrm{SO}_{4}$, filtered and concentrated in vacuo. The residue was purified by silica gel column chromatography $(\mathrm{AcOEt} / \mathrm{hexane}=1 / 3)$ to give aldehyde $18(63.8 \mathrm{mg}, 0.214 \mathrm{mmol}, 64 \%)$ as a colorless oil. 18: $[\alpha]_{\mathrm{D}}{ }^{26}-20.4$ (c 0.200, $\mathrm{CHCl}_{3}$ ); IR (neat): 3330, 2952, 1723, 1529, 1249, 1069, $838 \mathrm{~cm}^{-1}$; ${ }^{1} \mathrm{H}-\mathrm{NMR}$ (400 MHz, $\left.\mathrm{CDCl}_{3}\right): \delta 9.77(\mathrm{~s}, 1 \mathrm{H}), 4.76(\mathrm{~d}, J=7.3 \mathrm{~Hz}, 1 \mathrm{H}), 4.13(\mathrm{t}, J=8.7 \mathrm{~Hz}, 2 \mathrm{H}), 4.08(\mathrm{~d}, J=7.3$ Hz, 1H), 2.65 (brs, 2H), 2.23-2.15 (m, 2H), 1.77 (t, $J=2.4 \mathrm{~Hz}, 3 \mathrm{H}), 1.69-1.45(\mathrm{~m}, 4 \mathrm{H}), 0.96$ (t, $J=$ $8.7 \mathrm{~Hz}, 2 \mathrm{H}), 0.03$ (s, 9H): ${ }^{13} \mathrm{C}-\mathrm{NMR}\left(100 \mathrm{MHz}, \mathrm{CDCl}_{3}\right): \delta 200.9,156.2,118.2,78.4,76.2,63.1,49.0$, 34.0, 25.5, 18.4, 17.7, 3.4, -1.5; HRMS (FAB): calcd for $\mathrm{C}_{15} \mathrm{H}_{28} \mathrm{NO}_{3} \mathrm{Si}\left([\mathrm{M}+\mathrm{H}]^{+}\right)$298.1838, found 298.1851. 


\section{Pinacol ester 21}

To a solution of flame-dried $\mathrm{CrCl}_{2}(1.19 \mathrm{~g}, 9.68 \mathrm{mmol})$ in THF $(20 \mathrm{~mL})$ was added $\mathrm{Cl}_{2} \mathrm{CHB}(\mathrm{pin})^{16}$ (0.370 mL, $2.42 \mathrm{mmol})$ via syringe. Then, a solution of aldehyde $\mathbf{1 8}(361 \mathrm{mg}, 1.21 \mathrm{mmol})$ and LiI (649 $\mathrm{mg}, 4.84 \mathrm{mmol})$ in THF $(4 \mathrm{~mL})$ was added via cannula at $0{ }^{\circ} \mathrm{C}$. After being stirred for $5 \mathrm{~min}$, the reaction mixture was allowed to warm to room temperature. After being stirred for $7 \mathrm{~h}$, the reaction was quenched with $\mathrm{H}_{2} \mathrm{O}(40 \mathrm{~mL})$, and the mixture was extracted with EtOAc $(50 \mathrm{~mL} \times 3)$. The combined organic layers were washed with brine $(30 \mathrm{~mL})$, dried over $\mathrm{Na}_{2} \mathrm{SO}_{4}$, filtered, and concentrated in vacuo. The residue was purified by silica gel column chromatography (EtOAc/hexane $=1 / 10)$ to give pinacol ester $21(398 \mathrm{mg}, 0.944 \mathrm{mmol}, 78 \%, E / Z=>95: 5)$ as a colorless oil. 21: $[\alpha]_{\mathrm{D}}^{23}-33.5$ (c 0.237, $\left.\mathrm{CHCl}_{3}\right)$; IR (neat): $3334,2952,1696,1639,1529,1363,1250,1146,838$ $\mathrm{cm}^{-1} ;{ }^{1} \mathrm{H}-\mathrm{NMR}\left(400 \mathrm{MHz}, \mathrm{CDCl}_{3}\right): \delta 6.55(\mathrm{dt}, J=18.3 \mathrm{~Hz}, 6.8 \mathrm{~Hz}, 1 \mathrm{H}), 5.50(\mathrm{~d}, 18.3 \mathrm{~Hz}, 1 \mathrm{H}), 4.44$ (d, $J=8.7 \mathrm{~Hz}, 1 \mathrm{H}), 4.12(\mathrm{t}, J=8.3 \mathrm{~Hz}, 2 \mathrm{H}), 3.74(\mathrm{brs}, 1 \mathrm{H}), 2.35(\mathrm{~d}, J=4.8 \mathrm{~Hz}, 2 \mathrm{H}), 2.13(\mathrm{~d}, J=2.7$ $\mathrm{Hz}, 2 \mathrm{H}), 1.77(\mathrm{t}, J=2.7 \mathrm{~Hz}, 3 \mathrm{H}), 1.67-1.39(\mathrm{~m}, 4 \mathrm{H}), 1.26(\mathrm{~s}, 12 \mathrm{H}), 0.97(\mathrm{t}, J=8.3 \mathrm{~Hz}, 2 \mathrm{H}), 0.04(\mathrm{~s}$, 9H); ${ }^{13} \mathrm{C}-\mathrm{NMR}\left(100 \mathrm{MHz}, \mathrm{CDCl}_{3}\right): \delta 156.2,149.1,83.1,78.7,76.7,62.9,49.9,41.5,33.7,24.8,24.7$, 18.6, 17.7, 3.4, -1.5; HRMS (FAB): calcd for $\mathrm{C}_{22} \mathrm{H}_{40} \mathrm{NO}_{4} \mathrm{SiBK}\left([\mathrm{M}+\mathrm{K}]^{+}\right) 460.2457$, found 460.2434 .

\section{Dieneyne 24}


To a solution of pinacol ester $21(20.0 \mathrm{mg}, 0.0480 \mathrm{mmol})$ and $(E)$-1-iodo-1-pentene $\mathrm{e}^{22}(310 \mu \mathrm{L}, 0.333$ mmol $)$ in degassed DMSO $(0.48 \mathrm{~mL})$ were added $\mathrm{Cs}_{2} \mathrm{CO}_{3}(92.9 \mathrm{mg}, 0.285 \mathrm{mmol})$ and $2^{\text {nd }}$ generation XphosPd cycle $(3.74 \mathrm{mg}, 4.75 \mu \mathrm{mol})$ at room temperature. After stirring for $10 \mathrm{~min}$, the reaction mixture was warmed to $50{ }^{\circ} \mathrm{C}$ with stirring for $1.5 \mathrm{~h}$. The reaction was allowed to cool to room temperature and quenched with sat. $\mathrm{NH}_{4} \mathrm{Cl}(1 \mathrm{~mL})$. The mixture was extracted with EtOAc $(2 \mathrm{~mL} x$ 3). The combined organic layers were washed with brine $(1 \mathrm{~mL})$, dried over $\mathrm{Na}_{2} \mathrm{SO}_{4}$, filtered, and concentrated in vacuo. The residue was purified by silica gel column chromatography (EtOAc/hexane $=1 / 20)$ to give dieneyne $\mathbf{2 4}(14.1 \mathrm{mg}, 0.0388 \mathrm{mmol} 82 \%)$ as a white amorphous solid. 24: $[\alpha]_{\mathrm{D}}^{27}-26.3\left(c 0.291, \mathrm{CHCl}_{3}\right)$; IR (neat): 3329, 2954, 1692, 1531, 1250, 1062, 988, 860, $838 \mathrm{~cm}^{-}$ 1, ${ }^{1} \mathrm{H}-\mathrm{NMR}\left(400 \mathrm{MHz}, \mathrm{CDCl}_{3}\right): \delta 6.02(\mathrm{dd}, J=14.5,11.6 \mathrm{~Hz}, 2 \mathrm{H}), 5.60(\mathrm{dt}, 14.5,7.2 \mathrm{~Hz}, 1 \mathrm{H}), 5.50$ (dt, $J=14.5,7.2 \mathrm{~Hz}, 1 \mathrm{H}), 4.14$ (t, $J=8.2 \mathrm{~Hz}, 2 \mathrm{H}), 3.68$ (brs, 1H), 2.25 (dd, $J=7.8,7.2 \mathrm{~Hz}, 2 \mathrm{H}), 2.14$ (d, $J=2.8 \mathrm{~Hz}, 2 \mathrm{H}), 2.03(\mathrm{dt}, 7.2,7.2 \mathrm{~Hz}, 2 \mathrm{H}), 1.77(\mathrm{t}, J=2.8 \mathrm{~Hz}, 3 \mathrm{H}), 1.63-1.45$ (m, 4H), 1.45-1.34 (m, 2H), $0.96(\mathrm{t}, J=8.2 \mathrm{~Hz}, 2 \mathrm{H}), 0.90(\mathrm{t}, J=7.2 \mathrm{~Hz}, 3 \mathrm{H}), 0.03(\mathrm{~s}, 9 \mathrm{H}) ;{ }^{13} \mathrm{C}-\mathrm{NMR}\left(100 \mathrm{MHz}, \mathrm{CDCl}_{3}\right)$ : $\delta 156.3,133.6,133.4,130.1,126.7,78.8,75.8,62.8,50.5,38.4,34.6,33.8,25.4,22.5,18.6,17.7,13.7$, 3.4, -1.5; HRMS (EI): calcd for $\mathrm{C}_{21} \mathrm{H}_{37} \mathrm{NO}_{2} \mathrm{Si}\left(\mathrm{M}^{+}\right)$363.2594, found 363.2586 .

\section{Pinacol ester 25}

To a solution of dieneyne $\mathbf{2 4}(88.5 \mathrm{mg}, 0.243 \mathrm{mmol})$ in THF $(2.4 \mathrm{~mL})$ were added $\mathrm{CuCl}(7.22 \mathrm{mg}$, 
$0.0729 \mathrm{mmol}), \mathrm{NaO} t$-Bu (18.9 mg, $0.197 \mathrm{mmol}), \mathrm{PCy}_{3} \cdot \mathrm{HBF}_{4}(40.3 \mathrm{mg}, 0.109 \mathrm{mmol}), \mathrm{B}_{2} \mathrm{pin}_{2}(92.5$ $\mathrm{mg}, 0.365 \mathrm{mmol})$ and $\mathrm{MeOH}(0.098 \mathrm{~mL}, 2.43 \mathrm{mmol})$ at room temperature. After stirring for $5 \mathrm{~min}$, the reaction mixture was warmed to $40{ }^{\circ} \mathrm{C}$ with stirring for $1.5 \mathrm{~h}$. The reaction was quenched with $\mathrm{H}_{2} \mathrm{O}(2 \mathrm{~mL})$. The mixture was extracted with EtOAc $(5 \mathrm{~mL} \times 3)$. The combined organic extracts were washed with brine $(3 \mathrm{~mL})$, dried over $\mathrm{Na}_{2} \mathrm{SO}_{4}$, and concentrated in vacuo. The residue was purified by silica gel column chromatography $($ EtOAc/hexane $=1 / 15)$ to give pinacol ester $(\mathbf{2 5})(102 \mathrm{mg}, 0.208$ mmol, $86 \%$ ) as a colorless oil.

25: $[\alpha]_{\mathrm{D}}{ }^{17}-21.2\left(c 0.179, \mathrm{CHCl}_{3}\right)$; IR (neat): 3330, 2954, 1692, 1531, $1370 \mathrm{~cm}^{-1} ;{ }^{1} \mathrm{H}-\mathrm{NMR}(400 \mathrm{MHz}$, $\left.\mathrm{CDCl}_{3}\right): \delta 6.28(\mathrm{t}, J=6.8 \mathrm{~Hz}, 1 \mathrm{H}), 6.01(\mathrm{dd}, J=15.2,10.8 \mathrm{~Hz}, 2 \mathrm{H}), 5.60(\mathrm{dt}, J=15.2,6.8 \mathrm{~Hz}, 1 \mathrm{H})$, $5.49(\mathrm{dt}, J=15.2,7.2 \mathrm{~Hz}, 1 \mathrm{H}), 4.37(\mathrm{~d}, J=7.9 \mathrm{~Hz}, 1 \mathrm{H}), 4.19$ (t, $J=8.7 \mathrm{~Hz}, 2 \mathrm{H}), 3.66$ (brs, $1 \mathrm{H}), 2.26-$ $2.12(\mathrm{~m}, 2 \mathrm{H}), 2.06$ (brs, $2 \mathrm{H}), 2.03(\mathrm{td}, 7.3,6.8 \mathrm{~Hz}, 2 \mathrm{H}), 1.66(\mathrm{~s}, 3 \mathrm{H}), 1.60-1.36(\mathrm{~m}, 4 \mathrm{H}), 1.46-1.37$ (m, 2H), $1.26(\mathrm{~s}, 12 \mathrm{H}), 0.97(\mathrm{t}, J=8.7 \mathrm{~Hz}, 2 \mathrm{H}), 0.90(\mathrm{t}, J=7.3 \mathrm{~Hz}, 3 \mathrm{H}), 0.03(\mathrm{~s}, 9 \mathrm{H}) ;{ }^{13} \mathrm{C}-\mathrm{NMR}(100 \mathrm{MHz}$, $\left.\mathrm{CDCl}_{3}\right): \delta 156.3,145.8,140.7,134.3,117.7,83.1,83.0,62.7,50.3,39.6,34.5,28.4,27.7,26.0,25.2$, 24.6, 17.7, 14.2, 13.9, -1.5; HRMS (FAB): calcd for $\mathrm{C}_{27} \mathrm{H}_{51} \mathrm{NO}_{4} \mathrm{SiB}\left([\mathrm{M}+\mathrm{H}]^{+}\right)$492.3686, found 492.3665 .

\section{Vinyl iodide 26}

To a solution of pinacol ester $25(19.0 \mathrm{mg}, 0.0386 \mathrm{mmol})$ in THF $(0.39 \mathrm{~mL})$ was added $2 \mathrm{M}$ aq. $\mathrm{NaOH}$ 
$(0.116 \mathrm{~mL}, 0.232 \mathrm{mmol})$ at room temperature. After stirring for $1 \mathrm{~h}$, iodine $(14.7 \mathrm{mg}, 0.116 \mathrm{mmol})$ was added to the reaction mixture. After stirring for $2.5 \mathrm{~h}$, the reaction was quenched with sat. aq. $\mathrm{Na}_{2} \mathrm{~S}_{2} \mathrm{O}_{3}$. The mixture was extracted with EtOAc. The combined organic extracts were washed with brine, dried over $\mathrm{MgSO}_{4}$, and concentrated in vacuo. The residue was purified by silica gel column chromatography $($ EtOAc/hexane $=1 / 30)$ to give vinyl iodide $26(8.70 \mathrm{mg}, 0.0177 \mathrm{mmol}, 46 \%)$ as a colorless oil.

26: $[\alpha]_{\mathrm{D}}{ }^{22}-20.6\left(c 0.095, \mathrm{CHCl}_{3}\right)$; IR (neat): 3325, 2953, 1689, 1532, 1250, 1061, 987, 859, $837 \mathrm{~cm}^{-}$

1, ${ }^{1} \mathrm{H}-\mathrm{NMR}\left(400 \mathrm{MHz}, \mathrm{CDCl}_{3}\right): \delta 6.13(\mathrm{t}, J=7.3 \mathrm{~Hz}, 1 \mathrm{H}), 6.08-5.96(\mathrm{~m}, 2 \mathrm{H}), 5.65-5.57(\mathrm{~m}, 1 \mathrm{H}), 5.52-$ $5.43(\mathrm{~m}, 1 \mathrm{H}), 4.37(\mathrm{~d}, J=7.7 \mathrm{~Hz}, 1 \mathrm{H}), 4.13(\mathrm{t}, J=7.8 \mathrm{~Hz}, 1 \mathrm{H}), 3.67$ (brs, 1H), 2.36 (s, 3H), 2.24-2.18 (m, 2H), 2.07-2.01 (m, 4H), 1.62-1.27 (m, 4H), $0.97(\mathrm{t}, J=7.8 \mathrm{~Hz}, 2 \mathrm{H}), 0.90(\mathrm{t}, J=7.3 \mathrm{~Hz}, 3 \mathrm{H}), 0.04$ (s, 12H); ${ }^{13} \mathrm{C}-\mathrm{NMR}\left(100 \mathrm{MHz}, \mathrm{CDCl}_{3}\right): \delta 156.3,140.8,133.7,133.6,130.0,126.5,93.9,62.9,50.5$, $38.3,37.5,34.1,30.3,27.5,25.2,22.5,17.8,13.7,-1.5$; HRMS (FAB): calcd for $\mathrm{C}_{21} \mathrm{H}_{38} \mathrm{NO}_{2} \mathrm{SiKI}$ $\left([\mathrm{M}+\mathrm{K}]^{+}\right) 530.1354$, found 530.1328 .

\section{Amine 27}

To a solution of vinyl iodide $27(80.6 \mathrm{mg}, 0.164 \mathrm{mmol})$ in DMSO $(1.64 \mathrm{~mL})$ was added CsF (175 mg, $1.15 \mathrm{mmol}$ ) at room temperature. After stirring at $70{ }^{\circ} \mathrm{C}$ for $2 \mathrm{~h}$, the reaction was quenched with saturated aqueous $\mathrm{NH}_{4} \mathrm{Cl}(2 \mathrm{~mL})$. The reaction mixture was extracted with EtOAc $(5 \mathrm{~mL} x 3)$. The 
combined organic layers were washed with brine $(2 \mathrm{~mL})$, dried over $\mathrm{Na}_{2} \mathrm{SO}_{4}$, filtered, and concentrated in vacuo. The residue was purified by silica gel column chromatography $\left(\mathrm{MeOH} / \mathrm{CHCl}_{3}=1 / 80\right.$ to 1/10) to give amine 27 (46.3 $\mathrm{mg}, 0.133 \mathrm{mmol}, 81 \%)$ as a colorless oil.

27: $[\alpha]_{\mathrm{D}}{ }^{27}+5.9\left(c 0.065, \mathrm{CHCl}_{3}\right)$; IR (neat): 2926, 1456, $988 \mathrm{~cm}^{-1} ;{ }^{1} \mathrm{H}-\mathrm{NMR}\left(400 \mathrm{MHz}, \mathrm{CDCl}_{3}\right): \delta$ 6.16-6.00 (m, 3H), $5.63(\mathrm{dt}, J=14.5,7.3 \mathrm{~Hz}, 1 \mathrm{H}), 5.52(\mathrm{dt}, J=14.5,7.3 \mathrm{~Hz}, 1 \mathrm{H}), 5.29$ (brs, $2 \mathrm{H}), 2.98$ (brs, 1H), $2.36(\mathrm{~s}, 3 \mathrm{H}), 2.43-2.05(\mathrm{~m}, 2 \mathrm{H}), 2.04$ (q, $J=2.3 \mathrm{~Hz}, 2 \mathrm{H}), 1.64-1.36(\mathrm{~m}, 6 \mathrm{H}), 0.90$ (t, $J=7.3$ $\mathrm{Hz}, 3 \mathrm{H}) ;{ }^{13} \mathrm{C}-\mathrm{NMR}\left(100 \mathrm{MHz}, \mathrm{CDCl}_{3}\right): \delta 140.5,134.4,134.1,130.0,125.8,94.1,51.5,38.5,34.6$, 34.1, 30.3, 27.5, 25.1, 22.4, 13.7; HRMS (FAB): calcd for $\mathrm{C}_{15} \mathrm{H}_{27} \mathrm{NI}\left([\mathrm{M}+\mathrm{H}]^{+}\right) 348.1188$, found 348.1180.

\section{Fmoc-protected amine 10}

To a solution of amine $27(46.3 \mathrm{mg}, 0.133 \mathrm{mmol})$ in THF $(0.9 \mathrm{~mL})$ and $\mathrm{H}_{2} \mathrm{O}(0.4 \mathrm{~mL})$ were added $\mathrm{NaHCO}_{3}(12.3 \mathrm{mg}, 0.146 \mathrm{mmol})$ and $\mathrm{FmocCl}(42.3 \mathrm{mg}, 0.146 \mathrm{mmol})$ at $0{ }^{\circ} \mathrm{C}$. After stirring for $40 \mathrm{~min}$ at the same temperature, the mixture was quenched with sat. aq. $\mathrm{NH}_{4} \mathrm{Cl}(2 \mathrm{~mL})$, and extracted with EtOAc $(5 \mathrm{~mL} \times 3)$. The combined organic layers were washed with brine $(2 \mathrm{~mL})$, dried over $\mathrm{Na}_{2} \mathrm{SO}_{4}$, filtered, and concentrated under reduced pressure. The residue was purified by silica gel column chromatography $($ EtOAc/hexane $=1 / 15)$ to give Fmoc-amine $10(67.0 \mathrm{mg}, 0.112 \mathrm{mmol}, 84 \%)$ as a white solid. 
10: $[\alpha]_{\mathrm{D}}{ }^{24}-11.3\left(c 0.148, \mathrm{CHCl}_{3}\right)$; IR (neat): $3318,2946,1686,1541,1254,986,736 \mathrm{~cm}^{-1}$; ${ }^{1} \mathrm{H}-\mathrm{NMR}$

(600 MHz, $\left.\mathrm{CDCl}_{3}\right): \delta 7.77(\mathrm{~d}, J=7.7 \mathrm{~Hz}, 2 \mathrm{H}), 7.58(\mathrm{~d}, J=7.3 \mathrm{~Hz}, 2 \mathrm{H}), 7.40(\mathrm{dd}, J=7.7,7.2 \mathrm{~Hz}, 2 \mathrm{H})$,

$7.33(\mathrm{dd}, J=7.3,7.2 \mathrm{~Hz}, 2 \mathrm{H}), 6.16(\mathrm{t}, J=6.3 \mathrm{~Hz}, 1 \mathrm{H}), 6.06-5.94(\mathrm{~m}, 2 \mathrm{H}), 5.69-5.56(\mathrm{~m}, 1 \mathrm{H}), 5.55-$

$5.34(\mathrm{~m}, 1 \mathrm{H}), 4.53(\mathrm{~d}, J=6.8 \mathrm{~Hz}, 1 \mathrm{H}), 4.50-4.33(\mathrm{~m}, 2 \mathrm{H}), 4.20(\mathrm{t}, J=6.8 \mathrm{~Hz}, 1 \mathrm{H}), 3.68(\mathrm{brs}, 1 \mathrm{H})$, $2.35(\mathrm{~s}, 3 \mathrm{H}), 2.28-2.10(\mathrm{~m}, 2 \mathrm{H}), 2.08-1.97(\mathrm{~m}, 4 \mathrm{H}), 1.46-1.30(\mathrm{~m}, 6 \mathrm{H}), 0.89(\mathrm{t}, J=7.2 \mathrm{~Hz}, 3 \mathrm{H}) ;{ }^{13} \mathrm{C}-$ NMR (150 MHz, $\left.\mathrm{CDCl}_{3}\right): \delta 155.9,143.93,143.88,141.3,140.8,133.7,129.9,127.6,127.0,126.4$, 125.0, 119.9, 93.9, 66.3, 50.7, 47.3, 38.3, 34.6, 33.9, 30.3, 27.5, 25.2, 22.4, 13.7; HRMS (FAB): calcd for $\mathrm{C}_{30} \mathrm{H}_{36} \mathrm{INO}_{2}\left([\mathrm{M}+\mathrm{H}]^{+}\right) 570.1869$, found 570.1883 .

\section{Octanene 28}

To a solution of vinyl iodide 10 (14.0 mg, $0.0246 \mathrm{mmol})$ and vinyl stannane $9(36.5 \mathrm{mg}, 0.0386 \mathrm{mmol})$, which was prepared from (4R,5S)-4-\{[(4-methoxybenzyl)oxy]methyl $\}-2,2-$ dimethyl-5-(prop-1-yn-1yl)-1,3-dioxolane as described in the preceding paper, ${ }^{1}$ in DMF $(0.5 \mathrm{~mL})$ were added $\mathrm{LiCl}(2.1 \mathrm{mg}$, $0.0492 \mathrm{mmol})$ and $\mathrm{Ph}_{3} \mathrm{As}(7.5 \mathrm{mg}, 0.0246 \mathrm{mmol}), \mathrm{Pd}_{2}(\mathrm{dba})_{3}(6.4 \mathrm{mg}, 6.15 \mu \mathrm{mol})$ at room temperature. After stirring for $5 \mathrm{~min}$, the mixture was warmed to $40{ }^{\circ} \mathrm{C}$ and stirred for $2 \mathrm{~h}$. The reaction was quenched with pH 6.8 phosphate buffer $(1 \mathrm{~mL})$ and $\mathrm{H}_{2} \mathrm{O}(1 \mathrm{~mL})$, and the resulting mixture was extracted with EtOAc $(5 \mathrm{~mL} x 3)$. The combined organic layers were washed with brine $(1 \mathrm{~mL})$, dried over $\mathrm{Na}_{2} \mathrm{SO}_{4}$, filtered, and concentrated under reduced pressure. The residue was purified by silica gel 
column chromatography $(\mathrm{EtOAc} / \mathrm{hexane}=1 / 10)$ to give octaene $28(11.0 \mathrm{mg}, 0.0102 \mathrm{mmol}, 41 \%)$ as a colorless oil.

28: $[\alpha]_{\mathrm{D}}^{22}-14.7\left(c 0.166, \mathrm{CHCl}_{3}\right)$; IR (neat): 3337, 2953, 1790, 1744, 1715, 1616, 1523, 1450, 1234

$\mathrm{cm}^{-1} ;{ }^{1} \mathrm{H}-\mathrm{NMR}\left(400 \mathrm{MHz}, \mathrm{CDCl}_{3}\right): \delta 7.76(\mathrm{dd}, J=8.3,7.5 \mathrm{~Hz}, 4 \mathrm{H}), 7.59(\mathrm{dd}, J=18.6,7.5 \mathrm{~Hz}, 4 \mathrm{H})$, 7.43-7.37 (m, 5H), 7.32-7.28 (m, 4H), $6.61(\mathrm{~d}, J=15.8 \mathrm{~Hz}, 1 \mathrm{H}), 6.36(\mathrm{~d}, J=11.0 \mathrm{~Hz}, 1 \mathrm{H}), 6.33(\mathrm{~d}, J$ $=11.0 \mathrm{~Hz}, 1 \mathrm{H}), 6.23(\mathrm{~d}, J=15.1 \mathrm{~Hz}, 1 \mathrm{H}), 6.07-5.99(\mathrm{~m}, 5 \mathrm{H}), 5.71(\mathrm{~d}, J=9.8 \mathrm{~Hz}, 1 \mathrm{H}), 4.50-4.48(\mathrm{~m}$, 1H), 4.45-4.37 (m, 3H), $4.28(\mathrm{t}, J=7.5 \mathrm{~Hz}, 1 \mathrm{H}), 4.21(\mathrm{t}, J=6.5 \mathrm{~Hz}, 1 \mathrm{H}), 3.72$ (brs, $1 \mathrm{H}), 2.23-2.11(\mathrm{~m}$, 2H), 2.05-1.99 (m, 2H), $1.83(\mathrm{~s}, 3 \mathrm{H}), 1.74(\mathrm{~s}, 3 \mathrm{H}), 1.66-1.61(\mathrm{~m}, 3 \mathrm{H}), 1.43-1.25(\mathrm{~m}, 5 \mathrm{H}), 0.94-0.87$ (m, 21H), 0.57-0.52 (m, 12H); ${ }^{13} \mathrm{C}-\mathrm{NMR}\left(100 \mathrm{MHz}, \mathrm{CDCl}_{3}\right): \delta 168.7,167.1,145.9,145.8,144.0$, $141.3,138.9,134.0,133.7,133.68,133.66,131.1,130.4,130.0,127.8,127.6,127.1,127.0,125.2$, $125.1,125.0,122.0,120.0,119.94,119.86,73.2,72.9,70.6,66.4,50.9,47.4,46.9,40.8,38.3,34.7$, $29.1,25.9,25.5,22.5,17.5,13.7,13.2,12.4,6.8,4.9,0.0,-1.6$; HRMS (FAB): calcd for $\mathrm{C}_{70} \mathrm{H}_{91} \mathrm{NO}_{6} \mathrm{Si}_{2} \mathrm{~K}\left([\mathrm{M}+\mathrm{K}]^{+}\right)$1136.6022, found 1136.6050.

\section{Macrolactam 29}

To a solution of octaene $28(11.0 \mathrm{mg}, 0.0102 \mathrm{mmol})$ in $\mathrm{CH}_{2} \mathrm{Cl}_{2}(0.2 \mathrm{~mL})$ was added DBU $(6.1 \mu \mathrm{L}$, $0.0408 \mathrm{mmol}$ ) at $0{ }^{\circ} \mathrm{C}$. The reaction mixture was allowed to warm to room temperature and stirred for $1 \mathrm{~h}$. Then, THF (10 mL), HATU (38.7 mg, $0.102 \mathrm{mmol})$ and DIEPA ( $21 \mu \mathrm{L}, 0.122 \mathrm{mmol})$ were added 
to the reaction mixture. After stirring at room temperature for $16 \mathrm{~h}$, the reaction was quenched with pH 6.8 phosphate buffer $(5 \mathrm{~mL})$. The mixture was extracted with EtOAc $(5 \mathrm{~mL} x 3)$. The combined organic layers were washed with brine, dried over $\mathrm{Na}_{2} \mathrm{SO}_{4}$, filtered, and concentrated in vacuo. The residue was purified by silica gel column chromatography $($ EtOAc/hexane $=1 / 6)$ to give macrolactam 29 (4.6 $\mathrm{mg}, 66 \%$ overall) as a colorless oil.

29: ${ }^{1} \mathrm{H}-\mathrm{NMR}\left(400 \mathrm{MHz}\right.$, pyridine- $\left.d_{5}\right) \delta 8.10(\mathrm{~d}, J=9.6 \mathrm{~Hz}, 1 \mathrm{H}), 7.53(\mathrm{dd}, J=15.0,10.5 \mathrm{~Hz}, 1 \mathrm{H})$, 6.49-6.42 (m, 3H), 6.35-6.29 (m, 2H), 6.25-6.15 (m, 2H), $6.06(\mathrm{dd}, J=14.5,10.3 \mathrm{~Hz}, 1 \mathrm{H}), 5.84(\mathrm{t}, J$ $=10.1 \mathrm{~Hz}, 1 \mathrm{H}), 5.80-5.76(\mathrm{~m}, 1 \mathrm{H}), 5.63-5.59(\mathrm{~m}, 3 \mathrm{H}), 4.62(\mathrm{~d}, J=8.9 \mathrm{~Hz}, 1 \mathrm{H}), 4.60(\mathrm{brs}, 1 \mathrm{H}), 2.39-$ $2.35(\mathrm{~m}, 2 \mathrm{H}), 2.03-1.97(\mathrm{~m}, 3 \mathrm{H}), 1.86-1.83(\mathrm{~m}, 1 \mathrm{H}), 1.73(\mathrm{~s}, 3 \mathrm{H}), 1.62-1.58(\mathrm{~m}, 1 \mathrm{H}), 1.49-1.42(\mathrm{~m}$, $1 \mathrm{H}), 1.37-1.30(\mathrm{~m}, 2 \mathrm{H}), 1.28-1.23(\mathrm{~m}, 2 \mathrm{H}), 1.10-1.05(\mathrm{~m}, 18 \mathrm{H}), 0.84(\mathrm{t}, J=7.2 \mathrm{~Hz}, 3 \mathrm{H}), 0.83-0.69(\mathrm{~m}$, $12 \mathrm{H}) ;{ }^{13} \mathrm{C}-\mathrm{NMR}\left(150 \mathrm{MHz}\right.$, pyridine- $\left.d_{5}\right): \delta 169.0,143.6,141.5,139.4,139.1,134.7,134.6,133.4$, $133.2,131.5,130.8,130.1,129.4,126.8,125.7,122.4,75.9,72.5,51.3,39.7,37.4,35.3,30.8,27.3$, 23.2, 14.2, 13.1, 12.4, 7.55, 7.52, 5.74, 5.67; HRMS (EI): calcd for $\mathrm{C}_{41} \mathrm{H}_{69} \mathrm{NO}_{3} \mathrm{Si}_{2}\left(\mathrm{M}^{+}\right)$679.4816, found 679.4811 .

\section{6,17-Dihydroheronamide C (8)}

To a solution of macrolactam $29(4.6 \mathrm{mg}, 6.76 \mu \mathrm{mol})$ in THF $(0.7 \mathrm{~mL})$ was added TBAF $(27 \mu \mathrm{L}$, $0.0271 \mathrm{mmol}$ ) at $0{ }^{\circ} \mathrm{C}$. After stirring for $20 \mathrm{~min}$, the reaction was quenched with $\mathrm{pH} 6.8$ phosphate 
buffer $(1.0 \mathrm{~mL})$. The mixture was extracted with EtOAc $(5 \mathrm{~mL} \times 3)$ and the combined organic layers were washed with brine $(2 \mathrm{~mL})$, dried over $\mathrm{Na}_{2} \mathrm{SO}_{4}$, filtered, and concentrated under reduced pressure. The residue was purified by silica gel column chromatography $\left(\mathrm{MeOH} / \mathrm{CHCl}_{3}=1 / 20\right)$ to give macrolactam $8(2.0 \mathrm{mg}, 4.43 \mu \mathrm{mol}, 65 \%)$ as a white solid.

8: See Supporting Figure 3 for the CD spectrum; ${ }^{1} \mathrm{H}$ NMR $\left(600 \mathrm{MHz}\right.$, pyridine- $\left.d_{5}\right) \delta 8.07$ (d, $J=10.1$ Hz, 1H), $7.51(\mathrm{dd}, J=14.9,10.9 \mathrm{~Hz}, 1 \mathrm{H}), 6.45(\mathrm{~m}, 2 \mathrm{H}), 6.38(\mathrm{~m}, 2 \mathrm{H}), 6.28(\mathrm{~s}, 2 \mathrm{H}), 6.21(\mathrm{~m}, 2 \mathrm{H}), 6.05$ (dd, $J=15.0,10.5 \mathrm{~Hz}, 1 \mathrm{H}), 5.95(\mathrm{~d}, J=7.9 \mathrm{~Hz}, 1 \mathrm{H}), 5.77(\mathrm{~m}, 1 \mathrm{H}), 5.61(\mathrm{~m}, 1 \mathrm{H}), 5.56(\mathrm{dd}, J=8.9$, $5.4 \mathrm{~Hz}, 1 \mathrm{H}), 5.38(\mathrm{~d}, J=7.8 \mathrm{~Hz}, 1 \mathrm{H}), 5.01(\mathrm{~d}, J=8.9 \mathrm{~Hz}, 1 \mathrm{H}), 4.61(\mathrm{~s}, 1 \mathrm{H}), 2.35(\mathrm{~m}, 2 \mathrm{H}), 2.27$ (m, 1H), $1.99(\mathrm{~m}, 2 \mathrm{H}), 1.83(\mathrm{~s}, 3 \mathrm{H}), 1.68(\mathrm{~s}, 3 \mathrm{H}), 1.59(\mathrm{~m}, 1 \mathrm{H}), 1.43(\mathrm{~m}, 1 \mathrm{H}), 1.32(\mathrm{~m}, 2 \mathrm{H}), 1.23(\mathrm{~m}, 2 \mathrm{H})$, $0.82(\mathrm{t}, J=7.4 \mathrm{~Hz}, 3 \mathrm{H}) ;{ }^{13} \mathrm{C}$ NMR $\left(150 \mathrm{MHz}\right.$, pyridine- $\left.d_{5}\right) \delta 168.7,143.7,141.2,139.6,138.4,134.4$, 133.7, 132.94, 132.92, 132.91, 131.8, 131.1, 129.8, 129.0, 125.8, 124.8, 122.8, 73.8, 71.6, 50.9, 39.3, 36.9, 34.9, 30.4, 26.9, 22.7, 13.8, 12.7, 11.9; HRMS (ESI) calcd for $\mathrm{C}_{29} \mathrm{H}_{42} \mathrm{NO}_{3}[\mathrm{M}+\mathrm{H}]^{+} 452.3165$, found 452.3189 .

\section{Nonaene 31}

To a solution of vinyl iodide $12(14.2 \mathrm{mg}, 25.0 \mu \mathrm{mol})$ and vinyl stannane ent-9 $(15.0 \mathrm{mg}, 15.9 \mu \mathrm{mol})$ in DMF (0.32 mL) were added LiCl (1.35 mg, $31.8 \mu \mathrm{mol}), \mathrm{Ph}_{3} \mathrm{As}$ (4.87 mg, $\left.15.9 \mu \mathrm{mol}\right)$, and $\mathrm{Pd}_{2}(\mathrm{dba})_{3}$ . $\mathrm{CHCl}_{3}(4.10 \mathrm{mg}, 3.98 \mu \mathrm{mol})$ at room temperature. After stirring for $5 \mathrm{~min}$, the mixture was warmed 
to $40{ }^{\circ} \mathrm{C}$, and stirred further for $2 \mathrm{~h}$. The reaction was quenched by an addition of $\mathrm{pH} 6.8$ phosphate buffer $(1 \mathrm{~mL})$ and $\mathrm{H}_{2} \mathrm{O}(1 \mathrm{~mL})$, and the resultant mixture was extracted with EtOAc $(5 \mathrm{~mL} \times 3)$. The combined organic layers were washed with brine $(1 \mathrm{~mL})$, dried over $\mathrm{Na}_{2} \mathrm{SO}_{4}$, filtered, and concentrated in vacuo. The residue was purified by silica gel column chromatography $(\mathrm{EtOAc} / \mathrm{hexane}=1 / 10)$ to give nonaene $\mathbf{3 1}(6.87 \mathrm{mg}, 6.27 \mu \mathrm{mol}, 40 \%)$ as a colorless oil.

31: $[\alpha]_{\mathrm{D}}^{22}+14.7\left(c 0.166, \mathrm{CHCl}_{3}\right)$; IR (neat): 3337, 2953, 1790, 1744, 1715, 1616, 1523, 1450, 1234 $\mathrm{cm}^{-1} ;{ }^{1} \mathrm{H}-\mathrm{NMR}\left(600 \mathrm{MHz}, \mathrm{CDCl}_{3}\right): \delta 7.76(\mathrm{dd}, J=9.0,7.8 \mathrm{~Hz}, 4 \mathrm{H}), 7.62(\mathrm{~d}, J=7.2 \mathrm{~Hz}, 2 \mathrm{H}), 7.57$ (d, $J=7.8 \mathrm{~Hz}, 2 \mathrm{H}), 7.42-7.38(\mathrm{~m}, 5 \mathrm{H}), 7.33-7.28(\mathrm{~m}, 4 \mathrm{H}), 6.61(\mathrm{~d}, J=15.0 \mathrm{~Hz}, 1 \mathrm{H}), 6.50-6.42(\mathrm{~m}, 2 \mathrm{H})$, $6.35(\mathrm{dd}, J=15.0,11.4 \mathrm{~Hz}, 1 \mathrm{H}), 6.26(\mathrm{~d}, J=15.0 \mathrm{~Hz}, 1 \mathrm{H}), 6.13-5.99(\mathrm{~m}, 5 \mathrm{H}), 5.70(\mathrm{~d}, J=9.0 \mathrm{~Hz}$, 2H), $5.60(\mathrm{dt}, J=15.0,14.4 \mathrm{~Hz}, 1 \mathrm{H}), 5.52-5.46(\mathrm{~m}, 1 \mathrm{H}), 5.35(\mathrm{t}, J=16.2 \mathrm{~Hz}, 1 \mathrm{H}), 4.66(\mathrm{~d}, J=9.0 \mathrm{~Hz}$, 1H), 4.49 (dd, $J=8.4,4.8 \mathrm{~Hz}, 1 \mathrm{H}), 4.44(\mathrm{~d}, J=7.8 \mathrm{~Hz}, 2 \mathrm{H}), 4.39-4.37(\mathrm{~m}, 3 \mathrm{H}), 4.28(\mathrm{t}, J=7.2 \mathrm{~Hz}$, $1 \mathrm{H}), 4.21(\mathrm{t}, J=6.6 \mathrm{~Hz}, 1 \mathrm{H}), 3.88-3.77(\mathrm{~m}, 1 \mathrm{H}), 2.40-2.20(\mathrm{~m}, 4 \mathrm{H}), 2.03(\mathrm{q}, J=6.6 \mathrm{~Hz}, 2 \mathrm{H}), 1.85(\mathrm{~s}$, $3 \mathrm{H}), 1.84$ (s, 3H), 1.39 (sext, $J=7.2 \mathrm{~Hz}, 2 \mathrm{H}), 0.93-0.89(\mathrm{~m}, 21 \mathrm{H}), 0.57-0.52(\mathrm{~m}, 12 \mathrm{H}) ;{ }^{13} \mathrm{C}-\mathrm{NMR}(150$ $\left.\mathrm{MHz}, \mathrm{CDCl}_{3}\right): \delta 167.1,150.8,145.8,145.7,144.0,143.9,141.3,138.8,138.6,135.4,134.6,134.2$, $134.1,133.9,133.8,131.8,131.5,130.4,130.05,129.96,129.0,128.4,128.3,128.2,127.8,127.6$, 127.1, 127.0, 125.14, 125.10, 125.07, 120.01, 119.96, 119.9, 73.1, 72.9, 66.5, 66.3, 47.3, 46.9, 37.5, 34.7, 29.7, 22.4, 13.8, 13.7, 13.2, 12.6, 6.8, 4.8; HRMS (ESI): calced for $\mathrm{C}_{70} \mathrm{H}_{89} \mathrm{O}_{6} \mathrm{NNaSi}_{2}[\mathrm{M}+\mathrm{Na}]^{+}$ 1118.6121, found 1118.6115. 


\section{Macrolactam 32}

To a solution of nonaene $31(6.87 \mathrm{mg}, 6.27 \mu \mathrm{mol})$ in $\mathrm{CH}_{2} \mathrm{Cl}_{2}(0.13 \mathrm{~mL})$ was added DBU $(3.75 \mu \mathrm{L}$, $25.1 \mu \mathrm{mol})$ at $0{ }^{\circ} \mathrm{C}$. After stirring for $1 \mathrm{~h}$, THF $(6.3 \mathrm{~mL})$, HATU $(23.8 \mathrm{mg}, 0.627 \mathrm{mmol})$ and DIEPA $(13.1 \mu \mathrm{L}, 0.752 \mathrm{mmol})$ were added to the mixture. After stirring at room temperature for $16 \mathrm{~h}$, the reaction was quenched with an addition of $\mathrm{pH} 6.8$ phosphate buffer $(5 \mathrm{~mL})$. The mixture was extracted with EtOAc $(5 \mathrm{~mL} \times 3)$. The combined organic layers were washed with brine $(5 \mathrm{~mL})$, dried over $\mathrm{Na}_{2} \mathrm{SO}_{4}$, filtered, and concentrated in vacuo. The residue was purified by silica gel column chromatography $($ EtOAc/hexane $=1 / 6)$ to give macrolactam $32(2.25 \mathrm{mg}, 3.32 \mu \mathrm{mol}, 53 \%$ overall $)$ as a colorless oil.

32: ${ }^{1} \mathrm{H}-\mathrm{NMR}\left(600 \mathrm{MHz}\right.$, pyridine- $\left.d_{5}\right): \delta 7.85(\mathrm{~d}, J=10.2 \mathrm{~Hz}, 1 \mathrm{H}), 7.41(\mathrm{dd}, J=15.6,7.8 \mathrm{~Hz}, 1 \mathrm{H})$, $6.45(\mathrm{dd}, J=14.4,12.0 \mathrm{~Hz}, 1 \mathrm{H}), 6.37-6.25(\mathrm{~m}, 5 \mathrm{H}), 6.21-6.16(\mathrm{~m}, 1 \mathrm{H}), 6.12(\mathrm{~d}, J=11.4 \mathrm{~Hz}, 1 \mathrm{H}), 6.02$ (dd, $J=15.0,10.2 \mathrm{~Hz}, 1 \mathrm{H}), 5.87-5.80(\mathrm{~m}, 3 \mathrm{H}), 5.75(\mathrm{dt}, J=15.0,14.4 \mathrm{~Hz}, 1 \mathrm{H}), 5.59$ (dt, $J=15.0$, 14.4 Hz, 1H). $5.54(\mathrm{~d}, J=7.8 \mathrm{~Hz}, 1 \mathrm{H}), 4.65(\mathrm{~d}, J=8.4 \mathrm{~Hz}, 1 \mathrm{H}), 4.58-4.54(\mathrm{~m}, 1 \mathrm{H}), 3.69-3.55(\mathrm{~m}, 1 \mathrm{H})$, 2.53-2.51 (m, 2H), 2.44-2.34 (m, 2H), $1.96(\mathrm{q}, J=6.6 \mathrm{~Hz}, 2 \mathrm{H}), 1.86(\mathrm{~s}, 3 \mathrm{H}), 1.77$ (s, 3H), 1.31 (sext, $J=7.8 \mathrm{~Hz}, 2 \mathrm{H}), 1.08-1.03(\mathrm{~m}, 18 \mathrm{H}), 0.81(\mathrm{t}, J=7.8 \mathrm{~Hz}, 3 \mathrm{H}), 0.75-0.68(\mathrm{~m}, 12 \mathrm{H}) ;{ }^{13} \mathrm{C}-\mathrm{NMR}(150$ MHz, pyridine- $\left.d_{5}\right): \delta 162.1,142.9,140.7,138.8,137.2,134.5,132.5,131.7,131.1,130.9,130.6,130.5$, $130.4,130.3,129.1,128.3,125.3,124.1,74.6,71.3,49.7,41.0,38.4,34.3,29.4,22.1,13.2,12.0,6.6$, 
6.5, 4.73, 4.68; HRMS (ESI): calced for $\mathrm{C}_{41} \mathrm{H}_{68} \mathrm{O}_{3} \mathrm{NSi}_{2}[\mathrm{M}+\mathrm{H}]^{+} 678.4732$ found 678.4719.

\section{ent-Heronamide C (ent-1)}

To a cooled $\left(0{ }^{\circ} \mathrm{C}\right)$ solution of macrolactam $32(2.25 \mathrm{mg}, 3.32 \mu \mathrm{mol})$ in THF $(0.33 \mathrm{~mL})$ was added TBAF (1.0 M solution of in THF, $13.3 \mu \mathrm{L}, 13.3 \mu \mathrm{mol})$. The reaction was stirred at $0{ }^{\circ} \mathrm{C}$ for $30 \mathrm{~min}$. The reaction was quenched with $\mathrm{pH} 6.8$ phosphate buffer $(0.5 \mathrm{~mL})$. The resultant mixture was extracted with EtOAc ( $5 \mathrm{~mL}$ x 3). The combined organic layers were dried over $\mathrm{Na}_{2} \mathrm{SO}_{4}$, filtered, and concentrated in vacuo. The residue was purified by silica gel column chromatography $\left(\mathrm{MeOH} / \mathrm{CHCl}_{3}\right.$ $=1 / 20)$ to ent-heronamide C (ent-1) $(1.34 \mathrm{mg}, 2.98 \mu \mathrm{mol}, 90 \%)$ as a colorless oil. Spectroscopic data for ent-1 except for CD data (see Supporting Figure 3) were matched with those reported.

\section{Biological tests}

The growth inhibition and morphological changes by synthetic 8-deoxyheronamide $\mathrm{C}$ (2), entheronamide C (ent-1), and 16,17-dihydroheronamide C (8) were tested as described previously ${ }^{17}$ using the following fission yeast strains: JY1 $\left(h^{-}\right)$and $\operatorname{erg}$ mutants $^{18}\left(h^{-}\right.$ura4-C190T leu1-32 erg2::ura $4^{+}$; $h^{-}$ura4-C190T leu1-32 erg31::ura4-FOA ${ }^{\mathrm{R}}$ erg32::ura $\left.4^{+}\right)$.

\section{Supporting Information}

MD-simulated atom distribution and tilt angle of heronamides A-C, 8-deoxyheronamide $\mathrm{C}, 16,17$ - 
dehydroheronamide $\mathrm{C}$, and cholesterol in DMPC lipid bilayer; methods for the MD simulations; Raman spectra of heronamide $\mathrm{C}$ and 16,17-dehydroheronamide $\mathrm{C}$; methods for the Raman experiments; $\mathrm{CD}$ spectra of 8-deoxyheronamide C, ent-heronamide C, and 16,17-dehydroheronamide C; copies of the NMR spectra of synthesized compounds (PDF).

\section{Acknowledgement}

We thank Prof. Kaoru Takegawa (Kyushu University) for yeast strains. This work was supported in part by Grants-in-Aid for Scientific Research on Innovative Areas from the Ministry of Education, Culture, Sports, Science and Technology, Japan (no. 17H06401 to HK; no. $20 \mathrm{H} 04791$ to HS; no. $18 \mathrm{H} 04603$ to NK), a Grant-in-Aid for Scientific Research (C) from the Japan Society for the Promotion of Science (no. 19K06990 to NK, no. 19K05378 to HS), and a grant from the Tokyo Biochemical Research Foundation to NK. The molecular dynamics computations in this study were performed using the Advanced Center for Computing and Communication of RIKEN, the Research Center for Computational Science of the Institute for Molecular Science (IMS), and the Research Center for Advanced Computing Infrastructure of the Japan Advanced Institute of Science and Technology (JAIST).

\section{References}

(1) Kanoh, N.; Terajima, Y.; Tanaka, S.; Terashima, R.; Nishiyama, H.; Nagasawa, S.; Sasano, Y.; Iwabuchi, Y.; Nishimura, S.; Kakeya, H. Toward the Creation of Induced Pluripotent 
Small (iPS) Molecules: Establishment of Modular Synthetic Strategy to the Heronamide C-type Polyene Macrolactams and Their Conformational and Reactivity Analysis. ChemRxiv 2021, 10.33774/chemrxiv-2021-947db.

(2) Nishimura, S.; Matsumori, N. Chemical diversity and mode of action of natural products targeting lipids in the eukaryotic cell membrane. Nat Prod Rep 2020, 37, 677.

(3) Alvarez, R.; de Lera, A. R. Natural polyenic macrolactams and polycyclic derivatives generated by transannular pericyclic reactions: optimized biogenesis challenging chemical synthesis. Nat Prod Rep 2021, 38, 1136.

(4) Kakeya, H. Natural products-prompted chemical biology: phenotypic screening and a new platform for target identification. Nat Prod Rep 2016, 33, 648.

(5) Sugiyama, R.; Nishimura, S.; Matsumori, N.; Tsunematsu, Y.; Hattori, A.; Kakeya, H. Structure and Biological Activity of 8-Deoxyheronamide C from a Marine-Derived Streptomyces sp.: Heronamides Target Saturated Hydrocarbon Chains in Lipid Membranes. J Am Chem Soc 2014, 136, 5209.

(6) Kanoh, N.; Itoh, S.; Fujita, K.; Sakanishi, K.; Sugiyama, R.; Terajima, Y.; Iwabuchi, Y.; Nishimura, S.; Kakeya, H. Asymmetric total synthesis of heronamides A-C: Stereochemical confirmation and impact of long-range stereochemical communication on the biological activity. Chem-Eur J2016, 22, 8586.

(7) Raju, R.; Piggott, A. M.; Conte, M. M.; Capon, R. J. Heronamides A-C, new polyketide macrolactams from an Australian marine-derived Streptomyces sp A biosynthetic case for synchronized tandem electrocyclization. Org Biomol Chem 2010, 8, 4682.

(8) Fujita, K.; Sugiyama, R.; Nishimura, S.; Ishikawa, N.; Arai, M. A.; Ishibashi, M.; Kakeya, H. Stereochemical Assignment and Biological Evaluation of BE-14106 Unveils the Importance of One Acetate Unit for the Antifungal Activity of Polyene Macrolactams. J Nat Prod 2016, 79, 1877.

(9) Yamakoshi, H.; Dodo, K.; Okada, M.; Ando, J.; Palonpon, A.; Fujita, K.; Kawata, S.; Sodeoka, M. Imaging of EdU, an alkyne-tagged cell proliferation probe, by Raman microscopy. J Am Chem Soc 2011, 133, 6102.

(10) Yamakoshi, H.; Dodo, K.; Palonpon, A.; Ando, J.; Fujita, K.; Kawata, S.; Sodeoka, M. Alkyne-tag Raman imaging for visualization of mobile small molecules in live cells. $J$ Am Chem Soc 2012, 134, 20681.

(11) Miyaoka, R.; Hosokawa, M.; Ando, M.; Mori, T.; Hamaguchi, H. O.; Takeyama, H. In situ detection of antibiotic amphotericin B produced in Streptomyces nodosus using Raman microspectroscopy. Mar Drugs 2014, 12, 2827.

(12) Kamijo, S.; Dudley, G. B. Tandem nucleophilic addition/fragmentation reactions and synthetic versatility of vinylogous acyl triflates. JAm Chem Soc 2006, 128, 6499. 
(13) Hoover, J. M.; Stahl, S. S. Highly practical copper(I)/TEMPO catalyst system for chemoselective aerobic oxidation of primary alcohols. J Am Chem Soc 2011, 133, 16901.

(14) Sugiura, M.; Mori, C.; Kobayashi, S. Enantioselective transfer aminoallylation: Synthesis of optically active homoallylic primary amines. J Am Chem Soc 2006, 128, 11038.

(15) Ghosh, A. K.; Doung, T. T.; McKee, S. P.; Thompson, W. J. N,N` dissuccinimidyl carbonate: a useful reagent for alkoxycarbonylation of amines. Tetrahedron Lett 1992, 33, 2781.

(16) Takai, K.; Shinomiya, N.; Kaihara, H.; Yoshida, N.; Moriwake, T.; Utimoto, K. Transformation of Aldehydes into (E)-1-Alkenylboronic Esters with a Geminal Dichromium Reagent Derived from a Dichloromethylboronic Ester and Crcl2. Synlett 1995, 963.

(17) Nishimura, S.; Arita, Y.; Honda, M.; Iwamoto, K.; Matsuyama, A.; Shirai, A.; Kawasaki, H.; Kakeya, H.; Kobayashi, T.; Matsunaga, S.; Yoshida, M. Marine antifungal theonellamides target 3beta-hydroxysterol to activate Rho1 signaling. Nat Chem Biol2010, 6, 519.

(18) Iwaki, T.; Iefuji, H.; Hiraga, Y.; Hosomi, A.; Morita, T.; Giga-Hama, Y.; Takegawa, K. Multiple functions of ergosterol in the fission yeast Schizosaccharomyces pombe. Microbiology (Reading) 2008, 154, 830.

(19) Nakagawa, Y.; Umegawa, Y.; Nonomura, K.; Matsushita, N.; Takano, T.; Tsuchikawa, H.; Hanashima, S.; Oishi, T.; Matsumori, N.; Murata, M. Axial hydrogen at C7 position and bumpy tetracyclic core markedly reduce sterol's affinity to amphotericin B in membrane. Biochemistry 2015, 54, 303.

(20) Schaubach, S.; Gebauer, K.; Ungeheuer, F.; Hoffmeister, L.; Ilg, M. K.; Wirtz, C.; Furstner, A. A Two-Component Alkyne Metathesis Catalyst System with an Improved Substrate Scope and Functional Group Tolerance: Development and Applications to Natural Product Synthesis. Chemistry 2016, 22, 8494.

(21) Camerino, E.; Daniels, G. C.; Wynne, J. H.; Iezzi, E. B. Synthesis and kinetics of disassembly for silyl-containing ethoxycarbonyls using fluoride ions. $R s c A_{V} 2018,8,1884$.

(22) Barrett, A. G.; Bennett, A. J.; Menzer, S.; Smith, M. L.; White, A. J.; Williams, D. J. Applications of Crotonyldiisopinocampheylboranes in Synthesis: Total Synthesis of Restrictinol. JOrg Chem 1999, 64, 162. 